\title{
Major lung complications of systemic sclerosis
}

Christopher P. Denton ${ }^{1}$, Athol U. Wells ${ }^{2}$ and John G. Coghlan ${ }^{3}$

${ }^{1}$ UCL Division of Medicine, Royal Free Campus, London, UK

${ }^{2}$ Royal Brompton Hospital, London, UK

${ }^{3}$ Royal Free London NHS Foundation Trust, London, UK

\begin{abstract}
Systemic sclerosis ( $\mathrm{SSc}$ ) is associated with high mortality owing to internal organ complications and lung disease is the leading cause of SSc-associated death. The most notable lung complications in SSc are fibrosis and pulmonary arterial hypertension (PAH). A major challenge for the management of lung disease in SSc is detecting those patients with severe pathology and those patients that are likely to benefit from available treatments. In the past few, strategies for managing lung fibrosis and pulmonary hypertension, including PAH, have greatly progressed. For lung fibrosis, the tools to assess risk of progression and severity of the disease have been refined. Clinical trial results support the use of immunosuppression, including high intensity regimens with autologous stem cell transplantation. New trials are underway to test other potential therapies including treatments that are approved for use in idiopathic lung fibrosis. For PAH, identifying individuals at high risk of disease development is critical. In addition, individuals who have borderline elevation of pulmonary arterial pressure need to be appropriately managed and followed up. Many approved drugs targeting PAH are now available and results from large-scale clinical trials provide robust evidence that various treatments for SSc-associated $\mathrm{PAH}$ are associated with good long-term outcomes.
\end{abstract}




\section{[H1] Introduction}

Systemic sclerosis (SSc) is an uncommon disease characterized by fibrosis of the skin and internal organs and by vasculopathy. Amongst the autoimmune rheumatic diseases, systemic sclerosis has the highest mortality, which is mainly owing to the development of complications that affect the lungs $[1,2]$. The two most important lung complications in SSc are lung fibrosis, which reflects the tendency of SSc to cause scarring in the skin and internal organs, and pulmonary arterial hypertension (PAH), which reflects the cardinal proliferative vasculopathy that occurs in SSc $[3,4]$. SSc can be divided into two major clinical subsets on the basis of the extent of skin fibrosis: limited cutaneous SSc (IcSSc, affecting the face, neck and distal limbs) and diffuse cutaneous SSc (dcSSc, affecting the proximal limbs, abdomen and chest). These two major subsets also differ in the associated frequency and pattern of different SSc-associated autoantibodies and cardinal clinical characteristics [5].

The pathogenic mechanisms of lung fibrosis and pulmonary arterial hypertension are complex and incompletely understood but involve an interplay and cross talk between the cellular constituents of the lung. These complications are probably triggered by lung injury or damage in the epithelial and parenchymal compartments (for lung fibrosis) or the endothelium and pulmonary vasculature (for pulmonary hypertension) (Figure 1). Strategies for managing lung fibrosis and pulmonary hypertension, especially $\mathrm{PAH}$, have considerably advanced in the past few years. Major challenges in managing both conditions include the detection of patients with clinically meaningful disease, the identification of patients who are likely to benefit from intervention and the formulation of an optimal management plan that includes the treatment goals, the choice and dose of treatments and the means for efficiently monitoring patients.

With regard to lung fibrosis, new developments in our understanding of the pathogenesis have led to pivotal clinical trials of historical treatments and novel therapies. The search continues for treatments that might be as effective but are safer than current therapies. Several targeted biological therapies are being tested as one possible avenue. Likewise, the development of antifibrotic agents has made substantial progress. In addition, researchers are defining new tools for assessing the severity of lung fibrosis in SSc and the risk of progression, which should help improve the accuracy of treatment decisions.

In pulmonary hypertension, detecting patients with SSc at high risk of developing PAH, as well as differentiating patients with PAH from patients with other forms of pulmonary hypertension (including post-capillary disease), is challenging. Once a patient is diagnosed with $\mathrm{PAH}$, the effects of relevant comorbidities including other lung or heart complications on the patient's disease are important to consider.

The publication of the results of new clinical trials into the treatment of lung complications in SSc have advanced practice and provide an evidence base to support current treatments. For both lung fibrosis and $\mathrm{PAH}$, the concept of improving established disease and not just slowing progression is advancing. In this Review, we cover the major pulmonary aspects of SSc and discuss the current diagnostic approaches and treatment strategies.

\section{[H1] Pathogenesis}


Lung involvement in systemic sclerosis is best defined in terms of extrapulmonary features such as respiratory muscle weakness or skin fibrosis of the chest wall that might restrict breathing and includes pleural effusion, and intrapulmonary manifestations. The two major complications within the lung are lung fibrosis and pulmonary hypertension although other processes involving the lung parenchyma can also develop. Other less common forms of parenchymal disease such as organizing pneumonia. Pulmonary vascular disease includes pulmonary arterial hypertension (PAH) and other forms of pulmonary vasculopathy such as thromboembolic disease and pulmonary veno-occlusive disease. These forms of pulmonary vasculopathy should be distinguished from post-capillary pulmonary hypertension. These various lung complications can have shared underlying disease mechanisms (Figure 1).

\section{[H2] Pathogenesis of lung fibrosis}

Fibrosis is a general term describing the excessive formation of scarred or thickened tissue with excessive extracellular matrix in response to tissue damage, inflammation or as part of a specific process termed fibrogenesis in which activated fibroblasts or myofibroblasts produce excessive extracellular matrix. SSc-associated lung fibrosis probably shares common pathogenic mechanisms with other parenchymal lung diseases and with other manifestations of SSc. Multiple cell types and mediators are implicated in lung fibrogenesis [6,7], including lung epithelial cells (pneumocytes), inflammatory cells of all immune lineages and mesenchymal cells (including lung fibroblasts and myofibroblasts) [29,30]. Myofibroblasts are activated profibrotic contractile cells that resemble fibroblasts but are characterized by the expression of $\alpha$-smooth muscle actin; myofibroblasts are central to the development of fibrotic lung pathology (Figure 1).

Some clues about SSc pathogenesis have emerged from gene expression profiling studies of lung tissue and cultured fibroblasts $[8,9]$ as well as of other cells isolated from biopsy samples or obtained through broncho-alveolar lavage [10] including lymphocytes, mononuclear cells and fibrocytes. Functional studies have confirmed that lung fibroblasts have a profibrotic phenotype in SSc [11] and researchers have identified candidate pathways and regulators, including TGF $\beta$, CCL2 and IL13 that enhance extracellular matrix production and increase contractility and myofibroblast differentiation $[12,13,14]$. Studies of epithelial and endothelial cells from the lung tissue of patients with SSc-associated lung fibrosis also suggest a role for endothelial-mesenchymal and epithelial-mesenchymal transition in fibrotic lung pathology $[15,16]$, meaning that the pathogenic population of myofibroblasts has multiple potential lineages of origin that might contribute to excessive extracellular matrix deposition and obliteration of normal lung architecture. In addition, serum levels of IL-6, monocyte chemotactic protein 1 (MCP1; also known as CCL2) and CXC-chemokine ligand 4 (CXCL4) are associated with the occurrence and/or progression of lung fibrosis in SSc, implicating these factors as potential markers or mediators of lung fibrosis. $[17,18,19]$

As with other parenchymal lung diseases, environmental factors probably contribute to pathogenesis. In SSc, epithelial injury and damage resulting from aspiration or micro-aspiration are potentially involved in lung fibrogenesis. In one mouse strain, that is genetically susceptible to lung injury, the introduction of a mildly acidic saline solution into the lungs caused fibrosis [20]. This finding was consistent with human studies that have demonstrated the presence of epithelial injury (as measured by serum levels of Mucin1 (also known as KL-6) or clearance of aerosolized diethylenetriamine penta-acatate (DTPA) [21] in patients with SSc or have linked lung fibrosis severity with oesophageal reflux severity in SSc [22,23]. 
Epithelial injury might selectively activate profibrotic pathways including TGF $\beta$ signalling pathways, possibly via promoting conformational changes in the integrin-TGF $\beta$ complex. The involvement of epithelial injury and defective repair in lung fibrogenesis via increased TGF $\beta$ pathway activation is supported by the results from several relevant mouse models $[24,25]$ through local activation of TGF $\beta$ via integrin pathways or via post-natal activation of canonical receptor mediated signaling. .

Experimental findings of genetically modified mice with fibroblast-specific attenuation of TGF $\beta$ signalling further support a pivotal role for TGF $\beta$ signalling in the development of lung fibrosis and explant fibroblast studies are supported by analysis of SSc lung tissue that includes multiple cell types that may interact in vivo. A subpopulation of lung fibroblasts is speculated to co-ordinate repair and be involved in the regulation of fibrogenic cells from peripheral blood including fibrocytes $[26,27]$. Other lineages such as endothelial cells and lung epithelial cell lineages might also contribute to the fibrogenic population of cells in SSc. In the past few years, studies of mouse models have attempted to incorporate human tissue or have explored effect on human skin ex vivo. These studies suggest that chronic administration of bleomycin may give more consistent results and support an important potential role for circulating fibrogenic cells $[29,30]$.

Circulating and local resident monocyte-macrophage lineages are emerging as potential key effector cells in SSc lung fibrosis [16,31,32]. Analysis of genes expressed in the skin that are associated with severity of lung fibrosis [33] and a similar gene and protein analysis using a systems biology approach has contributed to a growing body of evidence implicating altered monocyte and macrophage function in the pathogenesis of SSc-associated lung fibrosis [34] based upon comparison of gene expression in different tissue substrates in SSc.

Genetic susceptibility might also be important in the development of lung fibrosis. A strong and consistent association exists between genetic risk factors (such as those identified by Immunochip analysis) and ANA patterns, providing support for a key role for the adaptive immune response in SSC pathogenesis [35]. Many genetic studies have been undertaken in SSc-associated lung fibrosis and a growing number of candidates have been identified from association studies or direct sequencing [36, $37,38,39]$. In general, immunological or inflammatory candidates seem to be more consistently identified in independent cohorts than factors relating to fibrosis, although in a complex heterogeneous disease such as SSc, the genetic associations from single cohorts might shed light on candidate pathways or mediators involved in pathogenesis even if conventional genetic replications across cohorts is not possible. This heterogeneity might reflect gene-environment interactions, differences in cofactors and other genetic or epigenetic differences between different study cohorts. For example, the association of SSC and a polymorphism in CTGF was reported by two independent single center cohorts [40,41] but not in another large multi-national study population [43]. Findings from two meta-analyses support a role for this polymorphism in patients from UK or Japanese backgrounds but not other [42]s, which could explain previous negative results [43, 44]. Epigenetic factors are potential contributors to SSC fibrogenesis; for example, particular microRNAs, including miR-155, are associated with lung fibrosis [45] and bromodomain inhibitors having potential anti-fibrotic effects in SSc lung fibroblasts [46]. Additional complex gene-environment interactions likely contribute to lung pathology in SSc; for example, experimental studies support a role for the microbiome, with early antibiotic exposure associated with increased susceptibility to experimental lung fibrosis in a scleroderma mouse model [47].

[H2] Pathogenesis of pulmonary hypertension 
The development of pulmonary hypertension in SSc and lung fibrosis have overlapping features. Vascular injury including pulmonary endothelial cell injury and endothelial dysfunction might be a key component in the development of both pathologies; vascular injury leads to an aberrant fibroproliferative or aberrant repair process that also results in an obliterative pulmonary vasculopathy [48]. SSc-associated PAH is histologically similar to idiopathic or hereditable PAH with muscularisation of intrapulmonary arterioles and medial thickening with perivascular inflammatory changes, although SScassociated PAH has a lower prevalence of endothelial proliferative and plexiform lesions than other forms of PAH [49]. SSc-associated PAH could even be a phenocopy of heritable PAH. The TGF $\beta$ receptor family member bone morphogenetic protein receptor type-2 (BMPR2) is implicated in the pathogenesis of a number of forms of PAH, notably hereditable disease and idiopathic PAH; reduced levels of BMPR2 in the lung blood vessels is associated with structural changes in the lung [50]. Interestingly, mouse models of SSc that implicate endothelial injury as a trigger of SSc-associated PAH also point towards a possible defect in BMPRII expression and function that could represent a unifying mechanism and potential susceptibility factor for several forms of PAH [51]. Hence, SSc might be a susceptibility phenotype for $\mathrm{PAH}$, which would explain why the risk of developing PAH is highest in established disease and continues through the course of follow up [52].

The mechanisms of PAH are likely complex and as with lung fibrosis probably involve multiple cell compartments that might contribute differently in different patients. Support for the role of immune cells in the development of SSc-associated PAH is emerging; on the basis of transcriptomic and serum analysis, macrophage or monocyte dysfunction, including M2 polarization, is associated with PAH development in SSc [53]. Endothelial cell to mesenchymal transition might also contribute to the fibroproliferative pathology seen in affected pulmonary vessels [54].

Other relevant pathogenic mediators include cytokines such as IL-6 and proliferative factors such as PDGF or CTGF that could be targeted with intracellular signalling inhibitors. The success of the antioxidant bardoxolone methyl in phase II trials of SSc-associated PAH points towards a possible role for cellular stress via mitochondrial dysfunction, oxidant stress and/or inflammation-induced damage in PAH pathogenesis. Recent studies implicate circulating adipsin, an adipokine that also regulates activation of the alternative complement pathway, in SSc-associated PAH pathogenesis [55], and some SSc-specific genetic susceptibility loci for PAH have been described [56] and analyzed [57], although no major associations have emerged. Thrombosis, which is an important contributor to CTEPH pathogenesis, is also evident in some patients with SSc- associated PAH, but not in patients without PAH (as observed using optical coherence tomography at initial time of diagnosis) [58]. Unfortunately, the risk to benefit ratio of anticoagulant use in patients with SSc-associated PAH is unfavorable, possibly because of the high frequency of gastrointestinal lesions in this population [59].

SSc-associated PAH might also share pathogenic mechanisms with other forms of pulmonary hypertension. In addition, factors that underlie other forms of pulmonary hypertension may be relevant. Thus, hypoxia is a key driver of group III pulmonary hypertension. Likewise, cardiac involvement is important for determining the development of pulmonary venous hypertension (PVHT) or group II pulmonary hypertension. It has been suggested, based on histological analysis, that SSc-associated PAH might often have components of PVOD, which could partially explain why some patients respond poorly to vasodilator therapy [60]. However, although PVOD is present in some patients with SSc-associated $\mathrm{PAH}$ on CT imaging, the overall frequency seems to be relatively low [61]. 


\section{[H1] Assessment of lung involvement}

Systematic approaches for screening and assessing patients with SSc for lung involvement are associated with greater ascertainment of major organ-based complications and improved long-term survival [62] compared to historic cohorts without regular screening. Thus, a comprehensive assessment at initial diagnosis followed by a regular systematic assessment of cardiorespiratory function is recommended for all patients with SSc [63]. This strategy is important for the management of lung disease, for a differential diagnosis and to help evaluate the treatment response, which can be challenging owing to the multiple mechanisms of disease and comorbidity. The investigation of lung involvement in SSc generally starts with a clinical examination and simple imaging such as chest radiography followed by formal lung function testing and CT imaging. Lung function tests include measures of lung volume such as total lung capacity (TLC) and forced vital capacity (FVC) and measures of gas exchange determined by the diffusing capacity for carbon monoxide (DLCO), which can be expressed for the whole lung or corrected for the measured alveolar volume (termed the gas transfer coefficient). CT imaging is the best way for evaluating lung fibrosis whereas a right heart catheterization is required for a formal diagnosis of pulmonary hypertension, even if already suspected on the basis of clinical features or echocardiography.

Exertional dyspnoea is a common presenting symptom in patients with either pulmonary fibrosis or pulmonary hypertension. Worsening exertional dyspnoea in patients with SSc is an important symptom that should prompt further evaluation for lung complications. However, the differential diagnosis for patients with SSc and dyspnoea is broad, reflecting the multiplicity of disease-related mechanisms and other confounding factors that contribute to dyspnoea (Box 1).

Loss of exercise tolerance in patients with SSc is commonly multifactorial. The cumulative effect of SSc and comorbidities on exercise capacity has been quantified using the Frailty index, which reflected the severity of dyspnoea [64]. Determining the contribution of cardiopulmonary limitation to exercise intolerance is difficult because of two important confounding factors: anxiety and fatigue. In patients with anxiety, hyperventilation might cause dyspnoea or heighten dyspnoea severity, especially in wellinformed patients who are sensitized to the dangers of cardiopulmonary involvement in SSc. Fatigue, a frequent source of disability in patients with SSc [65], might manifest as exercise intolerance and the distinction between limiting fatigue and limiting dyspnoea is often difficult to make.

In severe pulmonary fibrosis or PAH, prominent exercise intolerance can usually be confidently ascribed to lung involvement. However, in the remaining patients presenting with dyspnoea but without prominent exercise intolerance a form of exercise testing (the six-minute walk test) enables the assessment of cardiopulmonary function (using the point of oxygen desaturation as a measure of exercise tolerance), and this may identify other causes such as cardiac dysfunction $[66,67]$.

\section{[H2] Diagnosis of lung fibrosis}

All patients with SSc should be thoroughly examined for the presence of lung fibrosis at initial presentation and during follow up. Regular assessment increases the chance of detecting lung fibrosis early, thus enabling an early intervention. Currently, CT imaging is the best tool for detecting lung fibrosis and enables the pattern and extent of disease to be determined [68]. In addition, CT imaging seems to be more reliable than screening patients using lung function tests. The normal limits for lung function tests range from $80 \%$ to $120 \%$ of the average value for a person of the same sex, weight and 
height (as predicted by a computerized lung function test algorithm) and this wide range means that many patients with pulmonary fibrosis do not show overt impairment at initial screening [69]. However, lung function tests should still be performed at baseline and are the cornerstone of longitudinal follow up [52].

Other methods for assessing patients with SSc are available, such as routine chest radiography, exercise tolerance testing and dyspnoea scores, but these methods have limited use for detecting early pulmonary fibrosis. Routine chest radiography lacks the sensitivity for detecting pulmonary fibrosis but might be performed to assess other pathologies. Measures of exercise tolerance also have a limited sensitivity, probably owing to the confounding effects of extrathoracic manifestations of SSc [70], although measuring exercise tolerance might be valuable in the exclusion of clinically meaningful disease once lung fibrosis has been identified. Likewise, dyspnea scores are of limited use in the diagnosis of lung fibrosis but are valuable for trials or the longitudinal follow up of patients [71].

Although researchers have developed risk scores for the prediction of lung complications in patients with SSc (as discussed in the next section), at present a systematic approach for the screening and follow up of patients with SSc is important and justified by the high overall risk of developing severe lung fibrosis [52].

\section{[H2] Screening and diagnosis of pulmonary hypertension}

The high risk of pulmonary hypertension in SSc, and the major effect that pulmonary hypertension has on survival and quality of life [72], justifies the screening of patients. Hence, screening patients with SSc for pulmonary hypertension is recommended in clinical practice and a number of screening approaches have been developed. Patients should be screened for pulmonary hypertension at least once a year as early diagnosis can enable early treatment that could improve the long term outcome.

One of the first advocated screening approaches, developed as a result of the French itinerAIR study, used echocardiographic thresholds to prompt routine right heart catheterization [73]. In the past few years, other approaches have been developed that integrate lung function, echocardiography and the presence of other relevant markers such as N-terminal pro-brain natriuretic peptide (Nt-proBNP) [74]. Results from comparative studies suggest that these screening tools all perform well in clinical practice $[71,75,76]$. For example, one approach is to use the DETECT algorithm, an evidence-based tool that integrates non-invasive clinical and laboratory variables and echocardiography, to assess the risk of PAH (Figure 2) [77] DETECT was developed in a large cross-sectional cohort [77] to integrate non-invasive tests and minimize missed diagnoses of PAH. When considering lung function tests, it is important to consider that concurrent emphysema might reduce the utility of measuring gas exchange (DLCO) in patients for screening as it may increase FVC and diminish DLco independent of pulmonary hypertension. [78,79]. The DETECT cohort included patients with mild PAH and specific determinants of PAH progression have been elucidated using data from this cohort [80] and align with variables such as Nt-pro-BNP and low DLco identified in other cohorts [52, 81,82]. The DETECT algorithm first examines six variables (FVC, telangiectasia, ACA positivity, electrocardiogram right axis deviation and serum levels of Nt-pro-BNP and urate) to generate a score. If this score is above a defined threshold, an echocardiogram is recommended and various echocardiograph measures (the tricuspid regurgitant jet velocity and right atrial area) are used to generate the final DETECT score. If the DETECT score surpasses a defined threshold, a right heart catheterization is recommended as the patient has a significant risk of PAH. The DETECT score was devised from data of patients with SSc who had a disease duration of over 3 years and 
a predicted DLCO of $<60 \%$ (the DETECT cohort) and so this approach is best suited for use in such patients. Otherwise, echocardiography, lung function testing and measurements of Nt proBNP (Nterminal pro-brain natriuretic peptide), together with clinical assessment, are the main tools for assessing the risk of PAH.

Defining the presence of other connective tissue diseases in patients with SSc-associated pulmonary hypertension is important as patients with overlap features might benefit from concurrent immunosuppression [83]. All screening programmes can help identify patients with borderline elevation of mean pulmonary arterial pressure (mPAP), which is associated with distinct characteristics [84] and a high risk of developing PAH during follow up and so such patients need to be carefully monitored $[85,86]$. Defining the presence of increased pulmonary artery wedge pressure (PAWP) in SSc-associated $\mathrm{PAH}$ is also important as this feature can affect the disease outcome and reduce response to PAH specific therapy [87]. Mixed phenotypes with elements of lung disease and possible post-capillary components probably also occur and need careful evaluation and treatment to ensure that treatable precapillary components are defined and addressed [88]. In a 2017 study, patients with SSc-associated PAH who had a preserved pulmonary vascular bed (as assessed using optical coherence tomography $(\mathrm{OCT})$ at right heart catheterization to directly image the intrapulmonary vessel wall thickness and structure) showed a better response to PAH specific treatment than those patients with a damaged pulmonary circulation [58]. This finding is in line with other outcome studies suggesting that milder disease is associated with better outcomes than severe disease and fits with the current 2015 ERS/ESC recommendations for risk assessment and treatment [89].

Exercise testing could be an additional useful screening test for pulmonary hypertension but other musculoskeletal and extrathoracic manifestations might confound results [90,91]. More comprehensive risk prediction scores for pulmonary hypertension are in development but the value of these scores are presently limited and require validation. Identifying patients who have a very low risk of developing $\mathrm{PAH}$, and hence who do not require intensive screening, can be more important than identifying those at high risk. MRI is emerging as a non-invasive tool that might help stratify patients [92] and diagnose the presence of pulmonary hypertension but is not yet used in routine assessment of PAH-associated SSc. Autoantibodies, especially anti-U3 RNP, ACA, anti-RNA polymerase III and anti-Th/To RNP antibodies, are helpful in defining increased or reduced risk of PAH and are helpful in risk stratification [93]. The extent and severity of concurrent lung fibrosis is important as it might suggest a diagnosis of group III pulmonary hypertension and needs to be carefully defined [94].

\section{[H1] Classification of lung involvement}

\section{[H2] Classification of interstitial lung disease}

The classification of interstitial lung disease is complex but historically this disease has been subclassified on the basis of histological patterns observed in lung biopsy samples (Figure 3). The most common histological subtype that occurs in patients with SSc is non-specific interstitial pneumonia (NSIP) [67]. Although a sub-classification of NSIP was originally based upon histological patterns, correlations between lung biopsy and CT findings mean that patients with NSIP can be identified with high confidence using CT imaging [68]. NSIP can be further subdivided into reversible cellular NSIP and irreversible fibrotic NSIP subtypes based on the degree of inflammation present in the lung [95]. A minority of patients with SSc have another histological pattern referred to as usual interstitial pneumonia (UIP), which is the defining histological pattern of idiopathic pulmonary fibrosis. In idiopathic 
lung fibrosis the UIP pattern is associated with a much faster progression and worse survival than NSIP, however, the major prognostic distinction observed between NSIP and UIP patterns of disease (histologically or by CT imaging) in idiopathic pulmonary fibrosis does not apply to SSc-associated ILD. The outcome of SSc-associated ILD is much better than idiopathic pulmonary fibrosis [96] and the mortality is similar for patients with SSc-associated ILD and a NSIP pattern and those patients with a UIP pattern $[95,96]$.

Some patients with SSc can also have other forms of interstitial lung disease. For example, fibroelastosis is increasingly being recognized as a feature of connective tissue disease-associated ILD and can occur in association with pleural abnormalities and resembles idiopathics pleuroparenchymal fibroelastosis (a rare form of ILD with a poor prognosis). This form of ILD might be more progressive than other forms of SSc-associated ILD [97]. Currently, the precise frequency and clinical relevance of fibroelastosis in SSc-associated ILD is unknown [98]. Patients with overlap SSc, which represents up to $20 \%$ of patients with SSc [99], exhibit clinical features of the overlapping disease (for example, myositis or systemic lupus erythematosus (SLE)), which can include parenchymal lung disease. For example, myositis is associated with organizing pneumonia and SLE is associated with shrinking lung syndrome or lymphocytic interstitial pneumonias (LIP) [67].

Analyses of patient cohorts in the past few years has provided further insights into the timing and frequency of clinically important lung fibrosis development in SSc. Up to half of patients with dcSSc eventually develop severe lung fibrosis and many of these patients develop this complication within the first 3 years following diagnosis and can have considerable lung involvement at initial presentation $[52,100]$. This finding has important implications for treatment strategies aiming to prevent or attenuate worsening of disease. Overall, the frequency of lung fibrosis in patients with IcSSc is approximately half that of dcSSc (meaning approximately one quarter of patients with IcSSc are affected). Lung fibrosis is associated with different patterns of antinuclear antibodies (ANA), in particular anti-topoisomerase-1 antibodies. Approximately two thirds of patients that are positive for the anti-topoisomerase-1 ultimately develop moderate to severe ILD [5]. Other less common antinuclear antibodies (ANA) such as anti-U11/U12 ribonucleoprotein (RNP) antibodies or anti-Th/To RNP antibodies are also associated with lung fibrosis [101]. Interestingly, the presence of anti-centromere antibodies (ACA) or anti-RNA polymerase III antibodies (ARA) seems to be negatively associated with severe lung fibrosis $[100,101]$ and so presence of these can be used to identify cases at lower risk in clinical practice and encourage further investigation of respiratory symptoms.

\section{[H2] Stratification by lung fibrosis severity}

In clinical practice the most important aspect for managing lung fibrosis in patients with SSc is identifying those patients with severe disease or at risk of disease progression. By studying the factors associated with disease progression in well characterized cohorts, researchers have defined several key risk factors for developing severe lung fibrosis [52], which can be used in clinical practice (Box 2) The most important of these factors is the extent of disease severity, particularly in patients in the early stages of SSc.

The importance of determining lung fibrosis severity has led to the development of a simple staging system that incorporates CT assessment and measures of FVC. In practice, with this staging system patients are first stratified into whether they have clearly mild or extensive fibrosis $(<20 \%$ lung involvement or $>20 \%$ lung involvement, respectively, by high-resolution CT). In patients for whom the 
extent of fibrosis is indeterminable by $\mathrm{CT}$ imaging, they are instead stratified into these groups on the basis of FVC measurements ( $>70 \%$ for mild fibrosis and $<70 \%$ for extensive fibrosis) [102]. A designation of mild or extensive fibrosis by this staging system is associated with symptoms of dyspnoea and impaired exercise capacity [103]. This staging system can also reportedly predict an increased risk of considerable future decline; for example, $>20 \%$ lung involvement is associated with an increased risk of decline (as assessed by lung function tests) and decreased survival [104]. Other staging systems have also been suggested that are based on the analysis of large SSc cohorts [52] or clinical trial datasets $[105,106]$ and include features (such as arthritis) that might reflect clinical subtypes of SSc at high risk of developing fibrosis [107]. Other factors that potentially predict future decline include markers of epithelial damage, such as serum mucin-1 and DTPA clearance, and circulating markers, such as CXCL4 and IL-6, although IL- 6 is only predictive for patients with mild lung fibrosis $[17,108]$. At present, all of these measures are only useful in research settings pending further validation and standardization. In the future, composite markers that incorporate clinical and laboratory measures will probably be developed.

New approaches that use computer assisted quantitation of lung fibrosis are being developed $[109,110]$ and might offer further insights into disease progression and the refinement of staging systems in the future. As outlined above, baseline tests including CT imaging, lung function tests, ANA testing and the assessment of clinical features facilitate the stratification of individuals at high risk of developing severe lung disease for whom treatment is a high priority. Such approaches are especially useful in planning treatments such as haematopoietic stem cell transplantation (HSCT), which is associated with a high risk of treatment-related mortality but also long-term benefits such as increased survival [111]. New data suggest that in patients with extensive lung fibrosis (as designated by the severity staging system) [112], serial lung function testing can be used to monitor disease progression and predict mortality; for example, a drop of $>10 \%$ FVC at 12 months is the strongest single predictor of mortality). Additionally, a 5-9\% decline in FVC alongside a 15\% fall in DLCO at 12 months is also predictive of disease mortality. These thresholds might be useful in the evaluation of treatment responses, making treatment decisions and identifying patients for inclusion (or exclusion) in clinical trials [109]. Change in lung function, assessed by fall in FVC, is an important component of the newly developed composite response index for SSc clinical trials [113], and a decrease in lung function is associated with worse outcomes [114]. Finally, as discussed above, particular ANAs are also associated with an increased or decreased risk of lung fibrosis $[100,101]$.

\section{[H2] Classification of pulmonary hypertension}

The classification of pulmonary hypertension in SSc follows that of pulmonary hypertension associated with other diseases and it is important to consider the multiple way in which pulmonary hypertension can develop. Pulmonary hypertension is conventionally divided into five groups on the basis of clinical and pathobiological features (Table 1). Overall, PAH (classified by the WHO as group I) is probably the most frequent form of pulmonary hypertension, but mixed forms (such as pulmonary hypertension with lung fibrosis and cardiac involvement) also exist. More than half of patients with SSc-associated pulmonary hypertension have $\mathrm{PAH}$, but a considerable number of patients have post capillary pulmonary hypertension (WHO Group II) or pulmonary hypertension associated with lung fibrosis or hypoxia (WHO Group III) [52]. Pulmonary hypertension associated with lung fibrosis is generally defined as lung fibrosis affecting $>\mathbf{2 0} \%$ of the lung volume, although precise estimates of the extent of lung fibrosis can be challenging in routine clinical practice [115] and fibrosis can be exacerbated by the co- 
existent of emphysema [116]. In addition, some patients have concurrent pulmonary veno-occlusive disease (PVOD, WHO Group 1') or chronic thromboembolic pulmonary hypertension (CTEPH, WHO Group IV). The incidence rate of pulmonary hypertension of any form is approximately $1-2 \%$ per year in patients with SSc [52]. However, the frequency of pulmonary hypertension varies across different reports depending upon the duration of follow up; the frequency might be $5 \%$ for a cohort with an average disease duration of 5 years, $10 \%$ for a disease duration of 10 years and $15 \%$ for a disease duration of 15 years [52]. This increase in frequency differs from other complications of SSc, such as renal crisis, that generally occurs in early disease and is consistent with SSc representing a susceptibility phenotype for the development of pulmonary hypertension.

\section{[H1] Treatment approaches}

\section{[H2] Treatment approaches for lung fibrosis}

Immunosuppression remains the cornerstone for treatment of SSc-associated lung fibrosis. The benefits of immunosuppression are largely supported by findings from observation studies and retrospective studies $[116,117]$. However, limitations of the open label and retrospective design of most studies underpins the need for prospective randomized studies. A limited number of prospective clinical trials have been performed and show immunosuppression has beneficial effects. The most notable of these studies is the Scleroderma Lung Study I (SLS I) that compared oral cyclophosphamide over 12 months with placebo [118]. In this study, oral cyclophosphamide was efficacious but only had a marginal treatment benefit and substantial toxicity. However, the fact that the benefit observed was only small reflected the inclusion of many patients with mild non-progressive lung disease whereas post hoc subanalyses suggested that in extensive disease, cyclophosphamide therapy had major benefits in preventing disease progression, based on lung function testing. The results of a 2-year follow-up study suggested that the benefit of oral cyclophosphamide might continue to 18 months (the placebo subtracted difference at 18 months was 7\%) but was possibly attenuated by 24 months [119].

The Fibrosing Alveolitis in Scleroderma Trial (FAST) trial had a similar design to the SLS I trial but investigated 6 months of intravenous cyclophosphamide followed by oral azathioprine. After 12 months, the benefits of this treatment were no different from placebo, although FVC showed a trend towards improvement in the treatment group compared with the placebo group that did not reach statistical significance [120]. In the Scleroderma Lung Study II (SLS II), mycophenolate mofetil (MMF) was as efficacious as oral cyclophosphamide in improving cough-specific measurements [121], which was also observed when the data from both SLS studies were combined, to include the placebo control from SLS I [122] However, the tolerability of MMF was superior to cyclophosphamide and MMF is now used as a first line treatment in most centers [123]. The optimal dose of MMF for the treatment of SSc-associated ILD is probably $3 g /$ day, which was the target dose in the SLS II trial, although for patients who struggle to tolerate $3 / \mathrm{g}$ day, $2 \mathrm{~g} /$ day might be considered. Further support for immunosuppression in SSc lung fibrosis comes from the American Scleroderma Stem Cell versus Immunosuppression Trial (ASSIST) [124], the Autologous Stem cell Transplantation International Scleroderma ASTIS [111] trial and, in 2018, the Scleroderma: Cyclophosphamide or Transplantation (SCOT) study [125], which all compared intravenous cyclophosphamide with HSCT. In all three studies, HSCT was superior to cyclophosphamide therapy alone. However, the transplant-related mortality with HSCT was lower in the SCOT study than in the larger ASTIS trial. The SCOT study had a focus on lung fibrosis outcomes and in this study there was some impressive apparent improvement in established lung fibrosis, based upon computer assisted 
quantitative CT analysis, that point towards potential reversibility of lung fibrosis. However, HSCT remains a major undertaking and potential transplant-related mortality means that patients should be carefully selected for therapy, which emphasizes the value of staging or stratifying patients with SSc so that this therapy can be considered at a time when it might be best tolerated.

Although the SCOT study highlights the potential benefit of HSCT in treating SSc lung fibrosis, a similarly beneficial but less toxic treatment is necessary. Such a need is providing impetus for clinical trials that test biological strategies or the use of new agents in combination with immunosuppression such as MMF or B cell depletion with rituximab [126]. lung fibrosis such as IL-6R blockade can alter markers of fibrogenic macrophage differentiation or fibroblast activation [127] and tocilizumab (an IL-6 inhibitor) is being further tested in ongoing clinical trials of SSc [128]. The role of the adaptive immune compartment in SSc lung fibrosis development is supported by studies of lymphocytes isolated from bronchoalveolar lavage fluid [10] that show markers of T cell activation [10] and the association of lung fibrosis with specific antibody reactivities $[5,129]$. Thus, both $T$ cell and $B$ cell lineages might be relevant in lung fibrogenesis, which could explain the apparent benefit of immunosuppressive therapies in some patients [130]. For example, B cell depletion is effective in the treatment of some patients who are refractory to other therapies, providing strong support for the contribution of B cells to the pathogenic micro-environment in SSc-associated lung fibrosis [131].

Emerging clinical trials undertaken to test novel therapies include blockade of TGF $\beta$ [132] and its activation by epithelial alphav integrin [133] [https://clinicaltrials.gov/ct2/show/NCT02745145], the IL13-IL-4 axis and IL-4 [134]. In addition, two anti-fibrotic agents that can retard disease progression in idiopathic pulmonary fibrosis are currently undergoing evaluation in SSc-associated ILD: pirfenidone and nintedanib. Pirfenidone has already been evaluated in a small phase II study (LOTUSS) [135] and the SLS III trial comparing MMF combined with pirfenidone treatment and MMF treatment alone is ongoing [136] [https://clinicaltrials.gov/ct2/show/NCT03221257] A large phase III trial investigating the safety and efficacy of nintedanib in SSc-associated lung fibrosis is ongoing $[137,138$, https://clinicaltrials.gov/ct2/show/NCT02597933]. However, trials of lung fibrosis in SSc are challenging and some studies have failed to recruit enough patients [139] or have had unequivocally negative results $[140,141]$.

In addition to immunosuppression for patients with extensive fibrosis or those predicted to be at risk of lung disease progression, other general measures for the treatment of SSc-associated lung fibrosis include vigorous management of gastro-oesophageal reflux [142]. Combinations of antacids (acid suppressive agents) and prokinetics, as well as simple lifestyle measures, are used in the treatment of gastro-oesophageal reflux. Oxygen therapy can also be useful for reducing exertional dyspnoea and patients with severe lung disease might benefit from long term low dose oxygen therapy to reduce the risk of developing secondary pulmonary hypertension (WHO Group III). Oxygen therapy should be administered following general respiratory practice guidelines. Another important treatment approach in SSc-associated lung fibrosis is the management of infection. Prophylactic antibiotics should be considered for preventing community acquired infection in patients reporting frequent lower respiratory tract infections, and for preventing opportunistic infections such as pneumocystis in patients receiving long-term intensive immunosuppression [142].

[H2] Treatment approaches for $P A H$ 
PAH management has made substantial advances over the past 2 decades, especially regarding oral therapies and the growing evidence base for the use of drug combinations [143]. Therapies have progressed from a time when only intravenous epoprostenol was available $[144,145]$ and outcomes were very poor, to the current availability of multiple licensed treatments that can be used in combination (Table 2). The early studies that led to the licensing of various PAH therapies, including bosentan and sildenafil, focused on short term gains in exercise capacity; in these studies, the response of patients with SSc-associated PAH or CTD-associated PAH was often less efficacious than patients with other forms of $\mathrm{PAH}$, although most treatments seem to result in meaningful benefit in the majority of patients with SSc-associated PAH $[146,147,148,149]$. However, evidence in clinical practice suggests that these therapies have long-term benefits in SSc-associated PAH [142], which is supported by key eventdriven clinical trials published in the past 3 years $[150,151,152]$ : the SERAPHIN trial (which tested the oral endothelin receptor antagonist macitentan), the GRIPHON trial (which tested the prostcyclinreceptor agonist selexipag) and the AMBITION trial (which tested a combination therapy of ambrisentan (endothelin receptor antagonist) and tadalafil (a PDE5 inhibitor)).

Treatment strategies have defined key potential pathogenic and protective mechanisms in PAH. For example, endothelin (ET1), a potent vasoconstrictor and pro-proliferative peptide, is a probable pathogenic factor $[147,148]$. Whereas the nitric oxide pathway (which mediates vasodilation through soluble guanylate cyclase) is probably a protective factor as soluble guanylate cyclase stimulators and inhibitors of phosphodiesterase 5 (an enzyme that breaks down guanylate cyclase) have shown some promise in the treatment of SSc-associated PAH [143]. Similarly, prostacyclin-dependent pathways are protective and defects in these pathways might be important in pathogenesis [144]. The effectiveness of combination therapies, such as ambrisentan and tadalafil suggests that multiple pathways and mediators are likely involved in the development of PAH in SSc [153]

All the pivotal trials of new PAH treatments over the past few years have included considerable numbers of patients with CTD-associated PAH or SSc-associated PAH, which has enabled subgroup analyses and helped to establish licensed drugs for PAH in SSc (Table 3). The findings of these trials generally support the efficacy of specific licensed PAH treatments in PAH-associated SSC and are in line with emerging registry and retrospective cohort data [59]. The results of the three large, long-term event-driven trials were positive and suggest that these treatments are efficacious in patients with CTD-associated PAH, which is in line with the efficacy observed in the overall cohort that included patients with idiopathic or heritable PAH $[150,151,152,154,155]$. Studies of riociguat (a soluble guanylate cyclase stimulator) have shown similarly encouraging results in terms of long-term survival [156]; although the phase III trial examined exercise capacity as a primary end point and and showed less benefit in PAH-CTD, the earlier studies examined the six-minute walk test distance for which the response of patients with CTDassociated PAH or SSc-associated PAH was less overall than of patients with idiopathic $\mathrm{PAH}$ or the overall cohort [156]. Evidence-based recommendations are available for the treatment of pulmonary hypertension [89] and SSc-associated PAH [63]. Current recommendations support an aggressive use of combination treatments in patients with SSC at high risk of PAH [89], which is now recommended by most expert centers. Patients with mild $\mathrm{PAH}$ or those patients with mixed $\mathrm{PH}$ phenotypes might require a less aggressive treatment. Emerging evidence from cohort studies support the beneficial effects of intensive combination therapy (including a substantial improvement in survival) in the most severe cases of SSc-associated PAH [157]. 
The presence of cardiac disease or lung fibrosis is important to consider in SSc-associated PAH as these pathologies might occur concurrently, potentially resulting in a phenotype with a mixed aetiology that can affect the outcome and treatment response. For example, pulmonary vasodilators might be disadvantageous if they worsen the ventilation-perfusion ratio in pulmonary hypertension associated with lung fibrosis and detrimental in patients with a degree of post-capillary pulmonary hypertension owing to cardiac involvement. However, data from the GRIPHON study and other emerging data suggest that some patients with a degree of group II pulmonary hypertension in associated with PAH might benefit from specific PAH. The occurrence of PVOD and the risks associated with PVOD are also important to consider. PVOD occurring in SSc might be a mixed phenotype rather than a pure form of PVOD and could possibly respond to careful use of vasodilators [61]. Patients with complex forms of pulmonary hypertension should be managed by experts in SSc and experts in pulmonary hypertension collaboratively in specialist units to ensure that affected patients receive optimal treatment.

\section{[H2] Role of lung transplantation}

Lung transplantation is a potential treatment option for some patients with SSc who have pulmonary hypertension or lung fibrosis. However, choosing whether to use this treatment is difficult as lung transplantation is associated with a high frequency of relevant comorbidity including gastroesophageal reflux disease $[158,159]$. Challenges related to previous treatment, steroid use and gastro-oesophageal reflux are important as they may impact on post-transplant complications and outcome. [160]. However, case series from the past decade suggest that transplantation has favourable outcomes in many patients with SSc and long-term survival is comparable to that observed in patients with other multisystem diseases; hence, for some patients with SSc, heart, lung or combined transplantation is an important therapeutic option [161,162].

\section{[H1] Conclusions}

In this review, we highlight the ongoing challenges of lung complications in SSc but also provide clear evidence of the changing landscape in terms of understanding pathogenic mechanisms, assessing patients and providing treatments that effect outcomes [163]. The timing and frequency of lung fibrosis and pulmonary hypertension in SSc indicates that both complications are important and relatively frequent. An increasing understanding of pathogenetic pathways means that the expanding number of targeted biological or synthetic agents that target specific pathway or mediators can be tested and a better understanding of clinical trial design for lung fibrosis and PAH will ensure that the data obtained are robust and reliable. The situation is considerably more positive than a decade ago and tangible progress will probably be made over the next few years. The ultimate test will be increasing long term survival with better quality of life for patients with SSc, as observed after autologous stem cell transplantation [125].

Thus, despite the challenges of SSc there is reason to be optimistic because an unprecedented number of drugs are being tested in clinical trials for targeting lung and skin involvement in SSc, including treatments that might target fibrosis in both sites. Moreover, as the cost of PAH therapies becomes lower as generic formulations become available, opportunities arise to implement combination treatment at an early stage of disease. Identification of patients with a poor prognosis at an early stage of disease will enable better targeting of treatment and might start to diminish the high mortality seen 
in some patients with SSc $[164,165]$. High-quality recommendations and guidelines are now available $[63,166]$ that provide a roadmap for best practice and will undoubtedly be further updated as new evidence-based treatments for lung disease emerge. The future is bright as better tools for screening and diagnosis are being developed and a greater understanding of fundamental pathogenic mechanisms and identification of new potential therapeutic targets is being unveiled. Treatments for established lung complications are now available and various others are in clinical trials so that treatment approaches that prevent the progression of fibrosis and pulmonary hypertension will likely soon emerge as well as better ways to predict those at risk of major lung complications. 


\section{References}

1. Poudel DR, Jayakumar D, Danve A, Sehra ST, Derk CT. Determinants of mortality in systemic sclerosis: a focused review. Rheumatol Int. Nov 7. doi:10.1007/s00296-017-3826-y. [Epub ahead of print] (2017)

2. Hao Y, Hudson M, Baron M, Carreira P, Stevens W, Rabusa C, Tatibouet S, Carmona L, Joven BE, Huq M, Proudman S, Nikpour M; Canadian Scleroderma Research Group; Australian Scleroderma Interest Group. Early Mortality in a Multinational Systemic Sclerosis Inception Cohort. Arthritis Rheumatol. 69, 1067-1077 (2017).

3. Elhai M, Meune C, Boubaya M, Avouac J, Hachulla E, Balbir-Gurman A, Riemekasten G, Airò $P$, Joven B, Vettori S, Cozzi F, Ullman S, Czirják L, Tikly M, Müller-Ladner U, Caramaschi $P$, Distler O, lannone F, Ananieva LP, Hesselstrand R, Becvar R, Gabrielli A, Damjanov N, Salvador MJ, Riccieri V, Mihai C, Szücs G, Walker UA, Hunzelmann N, Martinovic D, Smith V, Müller CS, Montecucco CM, Opris D, Ingegnoli F, Vlachoyiannopoulos PG, Stamenkovic B, Rosato E, Heitmann S, Distler JHW, Zenone T, Seidel M, Vacca A, Langhe E, Novak S, Cutolo M, Mouthon L, Henes J, Chizzolini C, Mühlen CAV, Solanki K, Rednic S, Stamp L, Anic B, Santamaria VO, De Santis M, Yavuz S, Sifuentes-Giraldo WA, Chatelus E, Stork J, Laar JV, Loyo E, García de la Peña Lefebvre P, Eyerich K, Cosentino V, Alegre-Sancho JJ, KowalBielecka O, Rey G, Matucci-Cerinic M, Allanore Y; EUSTAR group. Mapping and predicting mortality from systemic sclerosis. Ann Rheum Dis, 76, 1897-1905 (2017).

4. Rubio-Rivas M, Simeón-Aznar CP, Velasco C, Marí-Alfonso B, Espinosa G, Corbella X, Colunga-Argüelles D, Egurbide-Arberas MV, Ortego-Centeno N, Vargas-Hitos JA, Freire M, Ríos-Blanco JJ, Trapiella-Martínez L, Rodríguez-Carballeira M, Fonollosa-Pla V; RESCLE investigators, Autoimmune Diseases Study Group (GEAS). Changes in the pattern of death of 987 patients with systemic sclerosis from 1990 to 2009 from the nationwide Spanish Scleroderma Registry (RESCLE). Clin Exp Rheumatol. 35 Suppl 106, 40-47 (2017).

5. $\quad$ Denton CP, Khanna D. Systemic sclerosis. Lancet. 390,1685-1699 (2017).

6. Denton CP. Systemic sclerosis: from pathogenesis to targeted therapy. Clin Exp Rheumatol. 33:S3-7 (2015).

7. Silver RM, Feghali-Bostwick CA. Editorial: molecular insights into systemic sclerosisassociated interstitial lung disease. Arthritis Rheumatol. 2014, 66, 485-7 (2014).

8. Hsu E, Shi H, Jordan RM, Lyons-Weiler J, Pilewski JM, Feghali-Bostwick CA. Lung tissues in patients with systemic sclerosis have gene expression patterns unique to pulmonary fibrosis and pulmonary hypertension. Arthritis Rheum. 63,783-94 (2011).

9. Lindahl GE, Stock CJ, Shi-Wen X, Leoni P, Sestini P, Howat SL, Bou-Gharios G, Nicholson AG, Denton CP, Grutters JC, Maher TM, Wells AU, Abraham DJ, Renzoni EA. Microarray profiling reveals suppressed interferon stimulated gene program in fibroblasts from sclerodermaassociated interstitial lung disease. Respir Res. 14, 80 (2013).

10. Goh NS, Veeraraghavan S, Desai SR, Cramer D, Hansell DM, Denton CP, Black CM, du Bois RM, Wells AU. Bronchoalveolar lavage cellular profiles in patients with systemic sclerosisassociated interstitial lung disease are not predictive of disease progression. Arthritis Rheum. 56:2005-12 (2007).

11. Shi-Wen X, Denton CP, McWhirter A, Bou-Gharios G, Abraham DJ, du Bois RM, Black CM. Scleroderma lung fibroblasts exhibit elevated and dysregulated type I collagen biosynthesis. Arthritis Rheum. 40, 1237-44 (1997). 
12. Shi-wen X, Kennedy L, Renzoni EA, Bou-Gharios G, du Bois RM, Black CM, Denton CP, Abraham DJ, Leask $A$. Endothelin is a downstream mediator of profibrotic responses to transforming growth factor beta in human lung fibroblasts. Arthritis Rheum. 56, 4189-94 (2007).

13. Shi-Wen X, Renzoni EA, Kennedy L, Howat S, Chen Y, Pearson JD, Bou-Gharios G, Dashwood MR, du Bois RM, Black CM, Denton CP, Abraham DJ, Leask A. Endogenous endothelin-1 signaling contributes to type I collagen and CCN2 overexpression in fibrotic fibroblasts. Matrix Biol. 26, 625-32 (2007).

14. Liu F, Lagares D, Choi KM, Stopfer L, Marinković A, Vrbanac V, Probst CK, Hiemer SE, Sisson TH, Horowitz JC, Rosas IO, Fredenburgh LE, Feghali-Bostwick C, Varelas X, Tager AM, Tschumperlin DJ. Mechanosignaling through YAP and TAZ drives fibroblast activation and fibrosis. Am J Physiol Lung Cell Mol Physiol. 308, L344-57 (2015).

15. Mendoza FA, Piera-Velazquez S, Farber JL, Feghali-Bostwick C, Jiménez SA. Endothelial Cells Expressing Endothelial and Mesenchymal Cell Gene Products in Lung Tissue From Patients With Systemic Sclerosis-Associated Interstitial Lung Disease. Arthritis Rheumatol. 68, 210-7 (2016).

16. Gilbane AJ, Denton CP, Holmes AM. Scleroderma pathogenesis: a pivotal role for fibroblasts as effector cells. Arthritis Res Ther. 15, 215 (2013).

17. De Lauretis A, Sestini P, Pantelidis P, Hoyles R, Hansell DM, Goh NS, Zappala CJ, Visca D, Maher TM, Denton CP, Ong VH, Abraham DJ, Kelleher P, Hector L, Wells AU, Renzoni EA. Serum interleukin 6 is predictive of early functional decline and mortality in interstitial lung disease associated with systemic sclerosis. J Rheumatol. 40, 435-46 (2013).

18. van Bon L, Affandi AJ, Broen J, Christmann RB, Marijnissen RJ, Stawski L, Farina GA, Stifano G, Mathes AL, Cossu M, York M, Collins C, Wenink M, Huijbens R, Hesselstrand R, Saxne T, DiMarzio M, Wuttge D, Agarwal SK, Reveille JD, Assassi S, Mayes M, Deng Y, Drenth JP, de Graaf J, den Heijer M, Kallenberg CG, Bijl M, Loof A, van den Berg WB, Joosten LA, Smith V, de Keyser F, Scorza R, Lunardi C, van Riel PL, Vonk M, van Heerde W, Meller S, Homey B, Beretta L, Roest M, Trojanowska M, Lafyatis R, Radstake TR. Proteome-wide analysis and CXCL4 as a biomarker in systemic sclerosis. N Engl J Med. 370, 433-43 (2014).

19. Wu M, Baron M, Pedroza C, Salazar GA, Ying J, Charles J, Agarwal SK, Hudson M, Pope J, Zhou X, Reveille JD, Fritzler MJ, Mayes MD, Assassi S. CCL2 in the Circulation Predicts LongTerm Progression of Interstitial Lung Disease in Patients With Early Systemic Sclerosis: Data From Two Independent Cohorts. Arthritis Rheumatol. 69, 1871-1878 (2017).

20. Denton CP, Zheng B, Evans LA, Shi-wen X, Ong VH, Fisher I, Lazaridis K, Abraham DJ, Black $\mathrm{CM}$, de Crombrugghe $\mathrm{B}$. Fibroblast-specific expression of a kinase-deficient type II transforming growth factor beta (TGFbeta) receptor leads to paradoxical activation of TGFbeta signaling pathways with fibrosis in transgenic mice. J Biol Chem. 278, 25109-19 (2013).

21. Goh NS, Desai SR, Anagnostopoulos C, Hansell DM, Hoyles RK, Sato H, Denton CP, Black CM, du Bois RM, Wells AU. Increased epithelial permeability in pulmonary fibrosis in relation to disease progression. Eur Respir J. 38, 184-90 (2011).

22. Richardson C, Agrawal R, Lee J, Almagor O, Nelson R, Varga J, Cuttica MJ, Dematte JD, Chang RW, Hinchcliff ME. Esophageal dilatation and interstitial lung disease in systemic sclerosis: $A$ cross-sectional study. Semin Arthritis Rheum. 46, 109-14 (2016). 
23. Christmann RB, Wells AU, Capelozzi VL, Silver RM Gastroesophageal reflux incites interstitial lung disease in systemic sclerosis: clinical, radiologic, histopathologic, and treatment evidence. Semin Arthritis Rheum. 40, 241-9 (2010)

24. Henderson NC, Arnold TD, Katamura Y, Giacomini MM, Rodriguez JD, McCarty JH, Pellicoro A, Raschperger E, Betsholtz C, Ruminski PG, Griggs DW, Prinsen MJ, Maher JJ, Iredale JP, Lacy-Hulbert A, Adams RH, Sheppard D. Targeting of av integrin identifies a core molecular pathway that regulates fibrosis in several organs. Nat Med. 19, 1617-24 (2013).

25. Sonnylal S, Denton CP, Zheng B, Keene DR, He R, Adams HP, Vanpelt CS, Geng YJ, Deng JM, Behringer RR, de Crombrugghe B. Postnatal induction of transforming growth factor beta signaling in fibroblasts of mice recapitulates clinical, histologic, and biochemical features of scleroderma. Arthritis Rheum. 56, 334-44 (2007).

26. Hoyles RK, Khan K, Shiwen X, Howat SL, Lindahl GE, Leoni P, du Bois RM, Wells AU, Black CM, Abraham DJ, Denton CP. Fibroblast-specific perturbation of transforming growth factor beta signaling provides insight into potential pathogenic mechanisms of scleroderma-associated lung fibrosis: exaggerated response to alveolar epithelial injury in a novel mouse model. Arthritis Rheum. 58, 1175-88 (2008).

27. Hoyles RK, Derrett-Smith EC, Khan K, Shiwen X, Howat SL, Wells AU, Abraham DJ, Denton CP. An essential role for resident fibroblasts in experimental lung fibrosis is defined by lineagespecific deletion of high-affinity type II transforming growth factor $\beta$ receptor. Am J Respir Crit Care Med. 183, 249-61 (2011).

28. Watanabe T, Nishimoto T, Mlakar L, Heywood J, Malaab M, Hoffman S, Feghali-Bostwick C. Optimization of a murine and human tissue model to recapitulate dermal and pulmonary features of systemic sclerosis. PLoS One. 12, e0179917 (2017).

29. Sun H, Zhu Y, Pan H, Chen X, Balestrini JL, Lam TT, Kanyo JE, Eichmann A, Gulati M, Fares WH, Bai H, Feghali-Bostwick CA, Gan Y, Peng X, Moore MW, White ES, Sava P, Gonzalez AL, Cheng Y, Niklason LE, Herzog EL. Netrin-1 Regulates Fibrocyte Accumulation in the Decellularized Fibrotic Sclerodermatous Lung Microenvironment and in Bleomycin-Induced Pulmonary Fibrosis. Arthritis Rheumatol. 2016, 68, 1251-61.

30. Martyanov V, Kim GJ, Hayes W, Du S, Ganguly BJ, Sy O, Lee SK, Bogatkevich GS, Schieven GL, Schiopu E, Marangoni RG, Goldin J, Whitfield ML, Varga J. Novel lung imaging biomarkers and skin gene expression subsetting in dasatinib treatment of systemic sclerosis-associated interstitial lung disease. PLoS One. 12:e0187580 (2017).

31. Tourkina E, Bonner M, Oates J, Hofbauer A, Richard M, Znoyko S, Visconti RP, Zhang J, Hatfield CM, Silver RM, Hoffman S. Altered monocyte and fibrocyte phenotype and function in scleroderma interstitial lung disease: reversal by caveolin-1 scaffolding domain peptide. Fibrogenesis Tissue Repair. 4, 15 (2011).

32. Misharin AV, Morales-Nebreda L, Reyfman PA, Cuda CM, Walter JM, McQuattie-Pimentel AC, Chen Cl, Anekalla KR, Joshi N, Williams KJN, Abdala-Valencia H, Yacoub TJ, Chi M, Chiu S, Gonzalez-Gonzalez FJ, Gates K, Lam AP, Nicholson TT, Homan PJ, Soberanes S, Dominguez S, Morgan VK, Saber R, Shaffer A, Hinchcliff M, Marshall SA, Bharat A, Berdnikovs S, Bhorade SM, Bartom ET, Morimoto RI, Balch WE, Sznajder JI, Chandel NS, Mutlu GM, Jain M, Gottardi CJ, Singer BD, Ridge KM, Bagheri N, Shilatifard A, Budinger GRS, Perlman H. Monocytederived alveolar macrophages drive lung fibrosis and persist in the lung over the life span. $J$ Exp Med. 214, 2387-2404 (2017). 
33. Assassi S, Wu M, Tan FK, Chang J, Graham TA, Furst DE, Khanna D, Charles J, Ferguson EC, Feghali-Bostwick C, Mayes MD. Skin gene expression correlates of severity of interstitial lung disease in systemic sclerosis. Arthritis Rheum. 65, 2917-27 (2013).

34. Taroni JN, Greene CS, Martyanov V, Wood TA, Christmann RB, Farber HW, Lafyatis RA, Denton CP, Hinchcliff ME, Pioli PA, Mahoney JM, Whitfield ML. A novel multi-network approach reveals tissue-specific cellular modulators of fibrosis in systemic sclerosis. Genome Med. 9, 27 (2017).

35. Mayes MD, Bossini-Castillo L, Gorlova O, Martin JE, Zhou X, Chen WV, Assassi S, Ying J, Tan FK, Arnett FC, Reveille JD, Guerra S, Teruel M, Carmona FD, Gregersen PK, Lee AT, López-Isac E, Ochoa E, Carreira P, Simeón CP, Castellví I, González-Gay MÁ; Spanish Scleroderma Group, Zhernakova A, Padyukov L, Alarcón-Riquelme M, Wijmenga C, Brown M, Beretta L, Riemekasten G, Witte T, Hunzelmann N, Kreuter A, Distler JH, Voskuyl AE, Schuerwegh AJ, Hesselstrand R, Nordin A, Airó P, Lunardi C, Shiels P, van Laar JM, Herrick A, Worthington J, Denton C, Wigley FM, Hummers LK, Varga J, Hinchcliff ME, Baron M, Hudson M, Pope JE, Furst DE, Khanna D, Phillips K, Schiopu E, Segal BM, Molitor JA, Silver RM, Steen VD, Simms RW, Lafyatis RA, Fessler BJ, Frech TM, Alkassab F, Docherty P, Kaminska E, Khalidi N, Jones HN, Markland J, Robinson D, Broen J, Radstake TR, Fonseca C, Koeleman BP, Martin J. Immunochip analysis identifies multiple susceptibility loci for systemic sclerosis. Am J Hum Genet. 94:47-61 (2014).

36. Stock CJ, Sato H, Fonseca C, Banya WA, Molyneaux PL, Adamali H, Russell AM, Denton CP, Abraham DJ, Hansell DM, Nicholson AG, Maher TM, Wells AU, Lindahl GE, Renzoni EA. Mucin 5B promoter polymorphism is associated with idiopathic pulmonary fibrosis but not with development of lung fibrosis in systemic sclerosis or sarcoidosis. Thorax. 68, 436-41 (2013).

37. Bossini-Castillo L, Simeon CP, Beretta L, Broen JC, Vonk MC, Ríos-Fernández R, Espinosa G, Carreira P, Camps MT, Castillo MJ, González-Gay MA, Beltrán E, Carmen Freire Md, Narváez J, Tolosa C, Witte T, Kreuter A, Schuerwegh AJ, Hoffmann-Vold AM, Hesselstrand R, Lunardi C, van Laar JM, Chee MM, Herrick A, Koeleman BP, Denton CP, Fonseca C, Radstake TR, Martin J; Spanish Scleroderma Group. A multicenter study confirms CD226 gene association with systemic sclerosis-related pulmonary fibrosis. Arthritis Res Ther. 14, R85 (2012).

38. Lagan AL, Pantelidis P, Renzoni EA, Fonseca C, Beirne P, Taegtmeyer AB, Denton CP, Black $\mathrm{CM}$, Wells AU, du Bois RM, Welsh KI. Single-nucleotide polymorphisms in the SPARC gene are not associated with susceptibility to scleroderma. Rheumatology (Oxford). 44, 197-201 (2005).

39. Chu H, Jiang S, Liu Q, Ma Y, Zhu X, Liang M, Shi X, Ding W, Zhou X, Zou H, Qian F, Shaul PW, Jin L, Wang J. Sirtuin1 Protects against Systemic Sclerosis-related Pulmonary Fibrosis by Decreasing Proinflammatory and Profibrotic Processes. Am J Respir Cell Mol Biol. 58, 28-39 (2018).

40. Fonseca $C$, Lindahl GE, Ponticos M, Sestini P, Renzoni EA, Holmes AM, Spagnolo P, Pantelidis P, Leoni P, McHugh N, Stock CJ, Shi-Wen X, Denton CP, Black CM, Welsh KI, du Bois RM, Abraham DJ. A polymorphism in the CTGF promoter region associated with systemic sclerosis. N Engl J Med. 357, 1210-20 (2007).

41. Kawaguchi $Y$, Ota $Y$, Kawamoto $M$, Ito I, Tsuchiya N, Sugiura T, Katsumata $Y$, Soejima M, Sato S, Hasegawa M, Fujimoto M, Takehara K, Kuwana M, Yamanaka H, Hara M. Association 
study of a polymorphism of the CTGF gene and susceptibility to systemic sclerosis in the Japanese population. Ann Rheum Dis. 68, 1921-4 (2001).

42. Rueda B, Simeon C, Hesselstrand R, Herrick A, Worthington J, Ortego-Centeno N, Riemekasten G, Fonollosa V, Vonk MC, van den Hoogen FH, Sanchez-Román J, Aguirre-

Zamorano MA, García-Portales R, Pros A, Camps MT, Gonzalez-Gay MA, Gonzalez-Escribano MF, Coenen MJ, Lambert N, Nelson JL, Radstake TR, Martin J. A large multicentre analysis of CTGF -945 promoter polymorphism does not confirm association with systemic sclerosis susceptibility or phenotype. Ann Rheum Dis. 68, 1618-20 (2009).

43. Zhang X, Nie S, Si X, Luo Y, Tang W. Association between the CTGF -945C/G polymorphism and systemic sclerosis: a meta-analysis. Gene. 509, 1-6 (2012).

44. Zhao W, Yue X, Liu K, Zheng J, Huang R, Zou J, Riemekasten G, Petersen F, Yu X. The status of pulmonary fibrosis in systemic sclerosis is associated with IRF5, STAT4, IRAK1, and CTGF polymorphisms. Rheumatol Int. 37, 1303-1310 (2017).

45. Christmann RB, Wooten A, Sampaio-Barros P, Borges CL, Carvalho CR, Kairalla RA, FeghaliBostwick C, Ziemek J, Mei Y, Goummih S, Tan J, Alvarez D, Kass DJ, Rojas M, de Mattos TL, Parra E, Stifano G, Capelozzi VL, Simms RW, Lafyatis R. miR-155 in the progression of lung fibrosis in systemic sclerosis. Arthritis Res Ther. 18, 155 (2016).

46. Tang X, Peng R, Phillips JE, Deguzman J, Ren Y, Apparsundaram S, Luo Q, Bauer CM, Fuentes ME, DeMartino JA, Tyagi G, Garrido R, Hogaboam CM, Denton CP, Holmes AM, Kitson C, Stevenson CS, Budd DC. Assessment of Brd4 inhibition in idiopathic pulmonary fibrosis lung fibroblasts and in vivo models of lung fibrosis. Am J Pathol. 183, 470-9 (2013).

47. Mehta H, Goulet PO, Mashiko S, Desjardins J, Pérez G, Koenig M, Senécal JL, Constante M, Santos MM, Sarfati M. Early-Life Antibiotic Exposure Causes Intestinal Dysbiosis and Exacerbates Skin and Lung Pathology in Experimental Systemic Sclerosis. J Invest Dermatol. 137, 2316-2325 (2017).

48. Avouac J, Guignabert C, Hoffmann-Vold AM, Ruiz B, Dorfmuller P, Pezet S, Amar O, Tu L, Van Wassenhove J, Sadoine J, Launay D, Elhai M, Cauvet A, Subramaniam A, Resnick R, Hachulla $E$, Molberg $\varnothing$, Kahan A, Humbert M, Allanore Y. Role of Stromelysin 2 (Matrix Metalloproteinase 10) as a Novel Mediator of Vascular Remodeling Underlying Pulmonary Hypertension Associated With Systemic Sclerosis. Arthritis Rheumatol. 69, 2209-2221 (2017).

49. Hemnes AR, Humbert M. Pathobiology of pulmonary arterial hypertension: understanding the roads less travelled. Eur Respir Rev. 26 (2017).

50. Davies RJ, Holmes AM, Deighton J, Long L, Yang X, Barker L, Walker C, Budd DC, Upton PD, Morrell NW. BMP type II receptor deficiency confers resistance to growth inhibition by TGF$\beta$ in pulmonary artery smooth muscle cells: role of proinflammatory cytokines. Am J Physiol Lung Cell Mol Physiol. 302, L604-15 (2012).

51. Gilbane AJ, Derrett-Smith E, Trinder SL, Good RB, Pearce A, Denton CP, Holmes AM. Impaired bone morphogenetic protein receptor II signaling in a transforming growth factor$\beta$-dependent mouse model of pulmonary hypertension and in systemic sclerosis. Am J Respir Crit Care Med. 191, 665-77 (2015).

52. Nihtyanova SI, Schreiber BE, Ong VH, Rosenberg D, Moinzadeh P, Coghlan JG, Wells AU, Denton CP. Prediction of pulmonary complications and long-term survival in systemic sclerosis. Arthritis Rheumatol. 66, 1625-35 (2014). 
53. Cheong FY, Gower AC, Farber HW. Changes in gene expression profiles in patients with pulmonary arterial hypertension associated with scleroderma treated with tadalafil. Semin Arthritis Rheum. 46, 465-472 (2017).

54. Good RB, Gilbane AJ, Trinder SL, Denton CP, Coghlan G, Abraham DJ, Holmes AM. Endothelial to Mesenchymal Transition Contributes to Endothelial Dysfunction in Pulmonary Arterial Hypertension. Am J Pathol. 185, 1850-8 (2015).

55. Korman BD, Marangoni RG, Hinchcliff M, Shah SJ, Carns M, Hoffmann A, Ramsey-Goldman R, Varga J. Brief Report: Association of Elevated Adipsin Levels With Pulmonary Arterial Hypertension in Systemic Sclerosis. Arthritis Rheumatol. 69, 2062-2068 (2017).

56. Bossini-Castillo L, Campillo-Davó D, López-Isac E, Carmona FD, Simeon CP, Carreira P, Callejas-Rubio JL, Castellví I, Fernández-Nebro A, Rodríguez-Rodríguez L, Rubio-Rivas M, García-Hernández FJ, Madroñero AB, Beretta L, Santaniello A, Lunardi C, Airó P, HoffmannVold AM, Kreuter A, Riemekasten G, Witte T, Hunzelmann N, Vonk MC, Voskuyl AE, de VriesBouwstra J, Shiels P, Herrick A, Worthington J, Radstake TRDJ, Martin J; Spanish Scleroderma Group. An MIF Promoter Polymorphism Is Associated with Susceptibility to Pulmonary Arterial Hypertension in Diffuse Cutaneous Systemic Sclerosis. J Rheumatol. 44, 1453-1457 (2017).

57. Garcia-Rivas G, Jerjes-Sánchez C, Rodriguez D, Garcia-Pelaez J, Trevino V. A systematic review of genetic mutations in pulmonary arterial hypertension. BMC Med Genet. 18:82 (2017).

58. Schwaiger JP, Loder CD, Dobarro D, Kaier T, Reddecliffe S, Schreiber BE, Handler C, Denton $\mathrm{CP}$, Coghlan JG. Optical coherence tomography evaluation of pulmonary arterial vasculopathy in Systemic Sclerosis. Sci Rep. 7, 43304 (2017).

59. Olsson KM1, Delcroix M, Ghofrani HA, Tiede H, Huscher D, Speich R, Grünig E, Staehler G, Rosenkranz S, Halank M, Held M, Lange TJ, Behr J, Klose H, Claussen M, Ewert R, Opitz CF, Vizza CD, Scelsi L, Vonk-Noordegraaf A, Kaemmerer H, Gibbs JS, Coghlan G, Pepke-Zaba J, Schulz U, Gorenflo M, Pittrow D, Hoeper MM. Anticoagulation and survival in pulmonary arterial hypertension: results from the Comparative, Prospective Registry of Newly Initiated Therapies for Pulmonary Hypertension (COMPERA). Circulation. 129, 57-65 (2014)

60. Daraban AM, Enache R, Predescu L, Platon P, Constantinescu T, Mihai C, Coman IM, Ginghina $C$, Jurcuţ R. Pulmonary veno-occlusive disease: a rare cause of pulmonary hypertension in systemic sclerosis. Case presentation and review of the literature. Rom J Intern Med. 175-83 (2015).

61. Connolly MJ, Abdullah S, Ridout DA, Schreiber BE, Haddock JA, Coghlan JG. Prognostic significance of computed tomography criteria for pulmonary veno-occlusive disease in systemic sclerosis-pulmonary arterial hypertension. Rheumatology (Oxford). 56, 2197-2203 (2017).

62. Nihtyanova SI, Tang EC, Coghlan JG, Wells AU, Black CM, Denton CP. Improved survival in systemic sclerosis is associated with better ascertainment of internal organ disease: a retrospective cohort study. QJM. 103, 109-15 (2010).

63. Denton CP, Hughes M, Gak N, Vila J, Buch MH, Chakravarty K, Fligelstone K, Gompels LL, Griffiths B, Herrick AL, Pang J, Parker L, Redmond A, van Laar J, Warburton L, Ong VH; BSR and BHPR Standards, Guidelines and Audit Working Group. BSR and BHPR guideline for the treatment of systemic sclerosis. Rheumatology (Oxford). 55, 1906-10 (2016). 
64. Guler SA, Kwan JM, Winstone TA, Milne KM, Dunne JV, Wilcox PG, Ryerson CJ. Severity and features of frailty in systemic sclerosis-associated interstitial lung disease. Respir Med, 129, 1-7 (2017).

65. Lumetti F, Barone L, Alfieri C, Silva M, Serra V, Delsante G, Sverzellati N, Ariani A. Quality of life and functional disability in patients with interstitial lung disease related to Systemic Sclerosis. Acta Biomed 86, 142-8 (2015)

66. Vacca A, Meune C, Gordon J, Chung L, Proudman S, Assassi S, Nikpour M, Rodriguez-Reyna TS, Khanna D, Lafyatis R, Matucci-Cerinic M, Distler O, Allanore Y; Scleroderma Clinical Trial Consortium Cardiac Subcommittee. Cardiac arrhythmias and conduction defects in systemic sclerosis. Rheumatology (Oxford). 53, 1172-7 (2014).

67. Wells $A U$, Denton CP. Interstitial lung disease in connective tissue disease--mechanisms and management. Nat Rev Rheumatol. 10, 728-39 (2014).

68. Desai SR, Veeraraghavan S, Hansell DM, Nikolakopolou A, Goh NS, Nicholson AG, Colby TV, Denton CP, Black CM, du Bois RM, Wells AU. CT features of lung disease in patients with systemic sclerosis: comparison with idiopathic pulmonary fibrosis and nonspecific interstitial pneumonia. Radiology. 232, 560-7 (2004).

69. Suliman YA, Dobrota R, Huscher D, Nguyen-Kim TD, Maurer B, Jordan S, Speich R, Frauenfelder T, Distler O. Brief Report: Pulmonary Function Tests: High Rate of FalseNegative Results in the Early Detection and Screening of Scleroderma-Related Interstitial Lung Disease. Arthritis Rheumatol 67:3256-61 (2015).

70. Buch $M H$, Denton $C P$, Furst $D E$, Guillevin $L$, Rubin $L J$, Wells $A U$, Matucci-Cerinic $M$, Riemekasten G, Emery P, Chadha-Boreham H, Charef P, Roux S, Black CM, Seibold JR. Submaximal exercise testing in the assessment of interstitial lung disease secondary to systemic sclerosis: reproducibility and correlations of the 6-min walk test. Ann Rheum Dis. 66, 169-73 (2007).

71. Khanna D, Gladue H, Channick R, Chung L, Distler O, Furst DE, Hachulla E, Humbert M, Langleben D, Mathai SC, Saggar R, Visovatti S, Altorok N, Townsend W, FitzGerald J, McLaughlin VV; Scleroderma Foundation and Pulmonary Hypertension Association. Recommendations for screening and detection of connective tissue disease-associated pulmonary arterial hypertension. Arthritis Rheum. 65, 3194-201 (2015).

72. Morrisroe K, Stevens W, Huq M, Prior D, Sahhar J, Ngian GS, Celermajer D, Zochling J, Proudman S, Nikpour M; Australian Scleroderma Interest Group (ASIG). Survival and quality of life in incident systemic sclerosis-related pulmonary arterial hypertension. Arthritis Res Ther. 19, 122 (2017).

73. Hachulla E, de Groote P, Gressin V, Sibilia J, Diot E, Carpentier P, Mouthon L, Hatron PY, Jego P, Allanore Y, Tiev KP, Agard C, Cosnes A, Cirstea D, Constans J, Farge D, Viallard JF, Harle JR, Patat F, Imbert B, Kahan A, Cabane J, Clerson P, Guillevin L, Humbert M; Itinér AIRSclérodermie Study Group. The three-year incidence of pulmonary arterial hypertension associated with systemic sclerosis in a multicenter nationwide longitudinal study in France. Arthritis Rheum. 60, 1831-9 (2009).

74. Thakkar V, Stevens W, Prior D, Youssef P, Liew D, Gabbay E, Roddy J, Walker JG, Zochling J, Sahhar J, Nash P, Lester S, Rischmueller M, Proudman SM, Nikpour M. The inclusion of Nterminal pro-brain natriuretic peptide in a sensitive screening strategy for systemic sclerosis- 
related pulmonary arterial hypertension: a cohort study. Arthritis Res Ther.

2013;15(6):R193. PMID: 24246100

75. Hao Y, Thakkar V, Stevens W, Morrisroe K, Prior D, Rabusa C, Youssef P, Gabbay E, Roddy J, Walker J, Zochling J, Sahhar J, Nash P, Lester S, Rischmueller M, Proudman SM, Nikpour M. A comparison of the predictive accuracy of three screening models for pulmonary arterial hypertension in systemic sclerosis. Arthritis Res Ther. 17, 7 (2015).

76. Schwaiger JP, Khanna D, Gerry Coghlan J. Screening patients with scleroderma for pulmonary arterial hypertension and implications for other at-risk populations. Eur Respir Rev. 22, 515-25 (2013).

77. Coghlan JG, Denton CP, Grünig E, Bonderman D, Distler O, Khanna D, Müller-Ladner U, Pope JE, Vonk MC, Doelberg M, Chadha-Boreham H, Heinzl H, Rosenberg DM, McLaughlin VV, Seibold JR; DETECT study group. Evidence-based detection of pulmonary arterial hypertension in systemic sclerosis: the DETECT study. Ann Rheum Dis. 73, 1340-9 (2014).

78. Antoniou KM, Margaritopoulos GA, Goh NS, Karagiannis K, Desai SR, Nicholson AG, Siafakas NM, Coghlan JG, Denton CP, Hansell DM, Wells AU. Combined Pulmonary Fibrosis and Emphysema in Scleroderma-Related Lung Disease Has a Major Confounding Effect on Lung Physiology and Screening for Pulmonary Hypertension. Arthritis Rheumatol. 68, 1004-12 (2016).

79. Schreiber BE, Valerio CJ, Keir GJ, Handler C, Wells AU, Denton CP, Coghlan JG. Improving the detection of pulmonary hypertension in systemic sclerosis using pulmonary function tests. Arthritis Rheum. 63, 3531-9 (2011).

80. Mihai C, Antic M, Dobrota R, Bonderman D, Chadha-Boreham H, Coghlan JG, Denton CP, Doelberg M, Grünig E, Khanna D, McLaughlin VV, Müller-Ladner U, Pope JE, Rosenberg DM, Seibold JR, Vonk MC, Distler O. Factors associated with disease progression in earlydiagnosed pulmonary arterial hypertension associated with systemic sclerosis: longitudinal data from the DETECT cohort. Ann Rheum Dis. 77, 128-132 (2018).

81. Sobanski V, Giovannelli J, Lynch BM, Schreiber BE, Nihtyanova SI, Harvey J, Handler CE, Denton CP, Coghlan JG. Characteristics and Survival of Anti-U1 RNP Antibody-Positive Patients With Connective Tissue Disease-Associated Pulmonary Arterial Hypertension. Arthritis Rheumatol. 68:484-93 (2016).

82. Valerio CJ, Schreiber BE, Handler CE, Denton CP, Coghlan JG. Borderline mean pulmonary artery pressure in patients with systemic sclerosis: transpulmonary gradient predicts risk of developing pulmonary hypertension. Arthritis Rheum. 65, 1074-84 (2013).

83. Visovatti SH, Distler O, Coghlan JG, Denton CP, Grünig E, Bonderman D, Müller-Ladner U, Pope JE, Vonk MC, Seibold JR, Torres-Martin JV, Doelberg M, Chadha-Boreham H, Rosenberg DM, McLaughlin VV, Khanna D. Borderline pulmonary arterial pressure in systemic sclerosis patients: a post-hoc analysis of the DETECT study. Arthritis Res Ther. 16, 493 (2014).

84. Bae S, Saggar R, Bolster MB, Chung L, Csuka ME, Derk C, Domsic R, Fischer A, Frech T, Goldberg A, Hinchcliff M, Hsu V, Hummers L, Schiopu E, Mayes MD, McLaughlin V, Molitor J, Naz N, Furst DE, Maranian P, Steen V, Khanna D. Baseline characteristics and follow-up in patients with normal haemodynamics versus borderline mean pulmonary arterial pressure in systemic sclerosis: results from the PHAROS registry. Ann Rheum Dis. 71, 1335-42 (2012).

85. Lammi MR, Saketkoo LA, Gordon JK, Lauto P, Fagan K, Steen VD; PHAROS Investigators. Clinical characteristics and survival of systemic sclerosis patients with pulmonary 
hypertension and elevated wedge pressure: Observations from the PHAROS cohort. Respirology. 22, 1386-1392 (2017).

86. Opitz CF, Hoeper MM, Gibbs JS, Kaemmerer H, Pepke-Zaba J, Coghlan JG, Scelsi L, D'Alto M, Olsson KM, Ulrich S, Scholtz W, Schulz U, Grünig E, Vizza CD, Staehler G, Bruch L, Huscher D, Pittrow D, Rosenkranz S. Pre-Capillary, Combined, and Post-Capillary Pulmonary Hypertension: A Pathophysiological Continuum. J Am Coll Cardiol. 68, 368-78 (2016).

87. Bae S, Saggar R, Bolster MB, Chung L, Csuka ME, Derk C, Domsic R, Fischer A, Frech T, Goldberg A, Hinchcliff M, Hsu V, Hummers L, Schiopu E, Mayes MD, McLaughlin V, Molitor J, Naz N, Furst DE, Maranian P, Steen V, Khanna D. Baseline characteristics and follow-up in patients with normal haemodynamics versus borderline mean pulmonary arterial pressure in systemic sclerosis: results from the PHAROS registry. Ann Rheum Dis. 71, 1335-42 (2012).

88. Chung L, Farber HW, Benza R, Miller DP, Parsons L, Hassoun PM, McGoon M, Nicolls MR, Zamanian RT. Unique predictors of mortality in patients with pulmonary arterial hypertension associated with systemic sclerosis in the REVEAL registry. Chest. 146, 14941504 (2014).

89. Galiè N, Humbert $M$, Vachiery JL, Gibbs S, Lang I, Torbicki A, Simonneau G, Peacock A, Vonk Noordegraaf A, Beghetti M, Ghofrani A, Gomez Sanchez MA, Hansmann G, Klepetko W, Lancellotti P, Matucci M, McDonagh T, Pierard LA, Trindade PT, Zompatori M, Hoeper M. 2015 ESC/ERS Guidelines for the diagnosis and treatment of pulmonary hypertension: The Joint Task Force for the Diagnosis and Treatment of Pulmonary Hypertension of the European Society of Cardiology (ESC) and the European Respiratory Society (ERS): Endorsed by: Association for European Paediatric and Congenital Cardiology (AEPC), International Society for Heart and Lung Transplantation (ISHLT). Eur Respir J. 46, 903-75 (2015).

90. Hager WD, Collins I, Tate JP, Azrin M, Foley R, Lakshminarayanan S, Rothfield NF. Exercise during cardiac catheterization distinguishes between pulmonary and left ventricular causes of dyspnea in systemic sclerosis patients. Clin Respir J. 7, 227-36 (2013).

91. Walkey AJ, leong M, Alikhan M, Farber HW. Cardiopulmonary exercise testing with rightheart catheterization in patients with systemic sclerosis. J Rheumatol. 37, 1871-7 (2010).

92. Ramjug S, Hussain N, Hurdman J, Billings C, Charalampopoulos A, Elliot CA, Kiely DG, Sabroe I, Rajaram S, Swift AJ, Condliffe R. Idiopathic and Systemic Sclerosis-Associated Pulmonary Arterial Hypertension: A Comparison of Demographic, Hemodynamic, and MRI Characteristics and Outcomes. Chest. 152, 92-102 (2017).

93. Steen VD, Lucas M, Fertig N, Medsger TA Jr. Pulmonary arterial hypertension and severe pulmonary fibrosis in systemic sclerosis patients with a nucleolar antibody. J Rheumatol. 34, 2230-5 (2007).

94. Michelfelder M, Becker M, Riedlinger A, Siegert E, Drömann D, Yu X, Petersen F, Riemekasten $\mathrm{G}$. Interstitial lung disease increases mortality in systemic sclerosis patients with pulmonary arterial hypertension without affecting hemodynamics and exercise capacity. Clin Rheumatol. 36, 381-390 (2017).

95. Bouros D, Wells AU, Nicholson AG, Colby TV, Polychronopoulos V, Pantelidis P, Haslam PL, Vassilakis DA, Black CM, du Bois RM. Histopathologic subsets of fibrosing alveolitis in patients with systemic sclerosis and their relationship to outcome. Am J Respir Crit Care Med. 165, 1581-6 (2002). 
96. Wells AU, Cullinan P, Hansell DM, Rubens MB, Black CM, Newman-Taylor AJ, Du Bois RM. Fibrosing alveolitis associated with systemic sclerosis has a better prognosis than lone cryptogenic fibrosing alveolitis. Am J Respir Crit Care Med 149, 1583-90 (1994).

97. Enomoto Y, Nakamura Y, Colby TV, Johkoh T, Sumikawa H, Nishimoto K, Yoshimura K, Matsushima S, Oyama Y, Hozumi H, Kono M, Fujisawa T, Enomoto N, Inui N, Iwashita T, Suda T. Radiologic pleuroparenchymal fibroelastosis-like lesion in connective tissue diseaserelated interstitial lung disease. PLoS One. 12, e0180283 (2017).

98. Hassoun D, Dirou S, Arrigoni PP, Durant C, Hamidou M, Néel A, Agard C. Radiological pleuroparenchymal fibroelastosis associated to limited cutaneous systemic sclerosis: a case report. BMC Pulm Med. 18, 73 (2018).

99. Pakozdi A, Nihtyanova S, Moinzadeh P, Ong VH, Black CM, Denton CP.Clinical and serological hallmarks of systemic sclerosis overlap syndromes. J Rheumatol. 38, 2406-9 (2011).

100. Nihtyanova SI, Denton CP. Scleroderma Lung Involvement, Autoantibodies, and Outcome Prediction: The Confounding Effect of Time. J Rheumatol. 44, 404-406 (2017).

101. Nihtyanova SI, Parker JC, Black CM, Bunn CC, Denton CP. A longitudinal study of anti-RNA polymerase III antibody levels in systemic sclerosis. Rheumatology (Oxford). 48, 1218-21 (2009).

102. Goh NS, Desai SR, Veeraraghavan S, Hansell DM, Copley SJ, Maher TM, Corte TJ, Sander CR, Ratoff J, Devaraj A, Bozovic G, Denton CP, Black CM, du Bois RM, Wells AU. Interstitial lung disease in systemic sclerosis: a simple staging system. Am J Respir Crit Care Med. 177, 124854 (2008).

103. Wallace B, Kafaja S, Furst DE, Berrocal VJ, Merkel PA, Seibold JR, Mayes MD, Khanna D. Reliability, validity and responsiveness to change of the Saint George's Respiratory Questionnaire in early diffuse cutaneous systemic sclerosis. Rheumatology (Oxford). 54, 1369-79 (2015).

104. Moore OA, Goh N, Corte T, Rouse H, Hennessy O, Thakkar V, Byron J, Sahhar J, Roddy J, Gabbay E, Youssef P, Nash P, Zochling J, Proudman SM, Stevens W, Nikpour M. Extent of disease on high-resolution computed tomography lung is a predictor of decline and mortality in systemic sclerosis-related interstitial lung disease. Rheumatology (Oxford). 52, 155-60 (2013).

105. Tashkin DP, Volkmann ER, Tseng CH, Kim HJ, Goldin J, Clements P, Furst D, Khanna D, Kleerup E, Roth MD, Elashoff R. Relationship between quantitative radiographic assessments of interstitial lung disease and physiological and clinical features of systemic sclerosis. Ann Rheum Dis. 75, 374-81 (2016).

106. Volkmann ER, Tashkin DP, Roth MD, Clements PJ, Khanna D, Furst DE, Mayes M, Charles J, Tseng $\mathrm{CH}$, Elashoff RM, Assassi S. Changes in plasma CXCL4 levels are associated with improvements in lung function in patients receiving immunosuppressive therapy for systemic sclerosis-related interstitial lung disease. Arthritis Res Ther. 18, 305 (2016).

107. Wu W, Jordan S, Becker MO, Dobrota R, Ye S, Maurer B, Distler O. Prediction of Progression of Interstitial Lung Disease in Patients with Systemic Sclerosis [abstract]. Arthritis Rheumatol. 2017; 69 (suppl 10). http://acrabstracts.org/abstract/prediction-of-progressionof-interstitial-lung-disease-in-patients-with-systemic-sclerosis/. Accessed May 23, 2018. 
108. Hoffmann-Vold AM, Aaløkken TM, Lund MB, Garen T, Midtvedt $\varnothing$, Brunborg C, Gran JT, Molberg $\varnothing$. Predictive value of serial high-resolution computed tomography analyses and concurrent lung function tests in systemic sclerosis. Arthritis Rheumatol. 67, 2205-12 (2015).

109. Khanna D, Nagaraja V, Tseng CH, Abtin F, Suh R, Kim G, Wells A, Furst DE, Clements PJ, Roth $M D$, Tashkin DP, Goldin J. Predictors of lung function decline in scleroderma-related interstitial lung disease based on high-resolution computed tomography: implications for cohort enrichment in systemic sclerosis-associated interstitial lung disease trials. Arthritis Res Ther. 17, 372 (2015).

110. Salaffi F, Carotti M, Di Donato E, Di Carlo M, Ceccarelli L, Giuseppetti G. Computer-Aided Tomographic Analysis of Interstitial Lung Disease (ILD) in Patients with Systemic Sclerosis (SSc). Correlation with Pulmonary Physiologic Tests and Patient-Centred Measures of Perceived Dyspnea and Functional Disability. PLoS One. 2016, 11, e0149240 (2016).

111. van Laar JM, Farge D, Sont JK, Naraghi K, Marjanovic Z, Larghero J, Schuerwegh AJ, Marijt EW, Vonk MC, Schattenberg AV, Matucci-Cerinic M, Voskuyl AE, van de Loosdrecht AA, Daikeler T, Kötter I, Schmalzing M, Martin T, Lioure B, Weiner SM, Kreuter A, Deligny C, Durand JM, Emery P, Machold KP, Sarrot-Reynauld F, Warnatz K, Adoue DF, Constans J, Tony HP, Del Papa N, Fassas A, Himsel A, Launay D, Lo Monaco A, Philippe P, Quéré I, Rich É, Westhovens R, Griffiths B, Saccardi R, van den Hoogen FH, Fibbe WE, Socié G, Gratwohl A, Tyndall A; EBMT/EULAR Scleroderma Study Group. Autologous hematopoietic stem cell transplantation vs intravenous pulse cyclophosphamide in diffuse cutaneous systemic sclerosis: a randomized clinical trial. JAMA. 311, 2490-8 (2014).

112. Goh NS, Hoyles RK, Denton CP, Hansell DM, Renzoni EA, Maher TM, Nicholson AG, Wells AU. Short-Term Pulmonary Function Trends Are Predictive of Mortality in Interstitial Lung Disease Associated With Systemic Sclerosis. Arthritis Rheumatol. 69, 1670-1678 (2017).

113. Khanna D, Berrocal VJ, Giannini EH, Seibold JR, Merkel PA, Mayes MD, Baron M, Clements PJ, Steen V, Assassi S, Schiopu E, Phillips K, Simms RW, Allanore Y, Denton CP, Distler O, Johnson SR, Matucci-Cerinic M, Pope JE, Proudman SM, Siegel J, Wong WK, Wells AU, Furst $D E$. The American College of Rheumatology Provisional Composite Response Index for Clinical Trials in Early Diffuse Cutaneous Systemic Sclerosis. Arthritis Rheumatol. 68, 299-311 (2016).

114. Moore OA, Proudman SM, Goh N, Corte TJ, Rouse H, Hennessy O, Morrisroe K, Thakkar V, Sahhar J, Roddy J, Youssef P, Gabbay E, Nash P, Zochling J, Stevens W, Nikpour M. Quantifying change in pulmonary function as a prognostic marker in systemic sclerosisrelated interstitial lung disease. Clin Exp Rheumatol. 33(4 Suppl 91): S111-6 (2015).

115. Chung L, Liu J, Parsons L, Hassoun PM, McGoon M, Badesch DB, Miller DP, Nicolls MR, Zamanian RT. Characterization of connective tissue disease-associated pulmonary arterial hypertension from REVEAL: identifying systemic sclerosis as a unique phenotype. Chest. 38, 1383-94 (2011).

116. Fischer A, Swigris JJ, Bolster MB, Chung L, Csuka ME, Domsic R, Frech T, Hinchcliff M, Hsu V, Hummers LK, Gomberg-Maitland M, Mathai SC, Simms R, Steen VD. Pulmonary hypertension and interstitial lung disease within PHAROS: impact of extent of fibrosis and pulmonary physiology on cardiac haemodynamic parameters. Clin Exp Rheumatol. 32, S109-14 (2014). 
117. Barnes H, Holland AE, Westall GP, Goh NS, Glaspole IN. Cyclophosphamide for connective tissue disease-associated interstitial lung disease. Cochrane Database Syst Rev. 1, CD010908. [Epub ahead of print] (2018)

118. Tashkin DP, Elashoff R, Clements PJ, Goldin J, Roth MD, Furst DE, Arriola E, Silver R, Strange C, Bolster M, Seibold JR, Riley DJ, Hsu VM, Varga J, Schraufnagel DE, Theodore A, Simms R, Wise R, Wigley F, White B, Steen V, Read C, Mayes M, Parsley E, Mubarak K, Connolly MK, Golden J, Olman M, Fessler B, Rothfield N, Metersky M; Scleroderma Lung Study Research Group. Cyclophosphamide versus placebo in scleroderma lung disease. N Engl J Med. 354, 2655-66 (2006).

119. Tashkin DP, Elashoff R, Clements PJ, Roth MD, Furst DE, Silver RM, Goldin J, Arriola E, Strange C, Bolster MB, Seibold JR, Riley DJ, Hsu VM, Varga J, Schraufnagel D, Theodore A, Simms R, Wise R, Wigley F, White B, Steen V, Read C, Mayes M, Parsley E, Mubarak K, Connolly MK, Golden J, Olman M, Fessler B, Rothfield N, Metersky M, Khanna D, Li N, Li G; Scleroderma Lung Study Research Group. Effects of 1-year treatment with cyclophosphamide on outcomes at 2 years in scleroderma lung disease. Am J Respir Crit Care Med. 176, 1026-34 (2007).

120. Hoyles RK, Ellis RW, Wellsbury J, Lees B, Newlands P, Goh NS, Roberts C, Desai S, Herrick AL, McHugh NJ, Foley NM, Pearson SB, Emery P, Veale DJ, Denton CP, Wells AU, Black CM, du Bois RM. A multicenter, prospective, randomized, double-blind, placebo-controlled trial of corticosteroids and intravenous cyclophosphamide followed by oral azathioprine for the treatment of pulmonary fibrosis in scleroderma. Arthritis Rheum. 54, 3962-70 (2006).

121. Tashkin DP, Volkmann ER, Tseng CH, Roth MD, Khanna D, Furst DE, Clements PJ, Theodore A, Kafaja S, Kim GH, Goldin J, Ariolla E, Elashoff RM. Improved Cough and Cough-Specific Quality of Life in Patients Treated for Scleroderma-Related Interstitial Lung Disease: Results of Scleroderma Lung Study II. Chest. 151, 813-820 (2017).

122. Volkmann ER, Tashkin DP, Li N, Roth MD, Khanna D, Hoffmann-Vold AM, Kim G, Goldin J, Clements PJ, Furst DE, Elashoff RM. Mycophenolate Mofetil Versus Placebo for Systemic Sclerosis-Related Interstitial Lung Disease: An Analysis of Scleroderma Lung Studies I and II. Arthritis Rheumatol. 69, 1451-1460 (2017).

123. Denton CP. Scleroderma Lung Study II-clarity or obfuscation? Lancet Respir Med, 4, 678-679 (2016).

124. Burt RK, Shah SJ, Dill K, Grant T, Gheorghiade M, Schroeder J, Craig R, Hirano I, Marshall K, Ruderman E, Jovanovic B, Milanetti F, Jain S, Boyce K, Morgan A, Carr J, Barr W. Autologous non-myeloablative haemopoietic stem-cell transplantation compared with pulse cyclophosphamide once per month for systemic sclerosis (ASSIST): an open-label, randomised phase 2 trial. Lancet. 378, 498-506 (2011).

125. Sullivan KM, Goldmuntz EA, Keyes-Elstein L, McSweeney PA, Pinckney A, Welch B, Mayes MD, Nash RA, Crofford LJ, Eggleston B, Castina S, Griffith LM, Goldstein JS, Wallace D, Craciunescu O, Khanna D, Folz RJ, Goldin J, St Clair EW, Seibold JR, Phillips K, Mineishi S, Simms RW, Ballen K, Wener MH, Georges GE, Heimfeld S, Hosing C, Forman S, Kafaja S, Silver RM, Griffing L, Storek J, LeClercq S, Brasington R, Csuka ME, Bredeson C, Keever-Taylor C, Domsic RT, Kahaleh MB, Medsger T, Furst DE; SCOT Study Investigators. Myeloablative Autologous Stem-Cell Transplantation for Severe Scleroderma. N Engl J Med. 378, 35-47 (2018). 
126. Saunders P, Tsipouri V, Keir GJ, Ashby D, Flather MD, Parfrey H, Babalis D, Renzoni EA, Denton CP, Wells AU, Maher TM. Rituximab versus cyclophosphamide for the treatment of connective tissue disease-associated interstitial lung disease (RECITAL): study protocol for a randomised controlled trial. Trials. 18, 275 (2017).

127. Denton $\mathrm{CP}$, Ong VH, Xu S, et al. Therapeutic interleukin- 6 blockade reverses transforming growth factor-beta pathway activation in dermal fibroblasts: insights from the faSScinate clinical trial in systemic sclerosisAnnals of the Rheumatic Diseases Published Online First: 31 May 2018. doi: 10.1136/annrheumdis-2018-213031 (2018)

128. Khanna D, Denton CP, Jahreis A, van Laar JM, Frech TM, Anderson ME, Baron M, Chung L, Fierlbeck G, Lakshminarayanan S, Allanore Y, Pope JE, Riemekasten G, Steen V, MüllerLadner U, Lafyatis R, Stifano G, Spotswood H, Chen-Harris H, Dziadek S, Morimoto A, Sornasse T, Siegel J, Furst DE. Safety and efficacy of subcutaneous tocilizumab in adults with systemic sclerosis (faSScinate): a phase 2, randomised, controlled trial. Lancet. 387, 2630-40 (2016).

129. Betteridge ZE, Woodhead F, Lu H, Shaddick G, Bunn CC, Denton CP, Abraham DJ, du Bois RM, Lewis M, Wells AU, McHugh NJ. Brief Report: Anti-Eukaryotic Initiation Factor 2B Autoantibodies Are Associated With Interstitial Lung Disease in Patients With Systemic Sclerosis. Arthritis Rheumatol. 68, 2778-2783 (2016).

130. Taher TE, Ong VH, Bystrom J, Hillion S, Simon Q, Denton CP, Pers JO, Abraham DJ, Mageed RA. Defective regulation of autoreactive IL-6-producing transitional $B$ lymphocytes is associated with disease in patients with systemic sclerosis. Arthritis Rheumatol. 2017 Nov 28. doi: 10.1002/art.40390.

131. Keir GJ, Maher TM, Hansell DM, Denton CP, Ong VH, Singh S, Wells AU, Renzoni EA. Severe interstitial lung disease in connective tissue disease: rituximab as rescue therapy. Eur Respir J. 40, 641-8 (2012).

132. Rice LM, Padilla CM, McLaughlin SR, Mathes A, Ziemek J, Goummih S, Nakerakanti S, York M, Farina G, Whitfield ML, Spiera RF, Christmann RB, Gordon JK, Weinberg J, Simms RW, Lafyatis R. Fresolimumab treatment decreases biomarkers and improves clinical symptoms in systemic sclerosis patients. J Clin Invest. 125, 2795-807 (2015).

133. http://www.clinicaltrials.gov/ct2/show/NCT02745145

134. http://www.clinicaltrials.gov/ct2/show/NCT02745145

135. Khanna D, Albera C, Fischer A, Khalidi N, Raghu G, Chung L, Chen D, Schiopu E, Tagliaferri M, Seibold JR, Gorina E. An Open-label, Phase II Study of the Safety and Tolerability of Pirfenidone in Patients with Scleroderma-associated Interstitial Lung Disease: the LOTUSS Trial. J Rheumatol. 43, 1672-9 (2016)

136. http://www.clinicaltrials.gov/ct2/show/NCT03221257

137. Distler O, Brown KK, Distler JHW, Assassi S, Maher TM, Cottin V, Varga J, Coeck C, Gahlemann M, Sauter W, Schmidt H, Highland KB; SENSCIS ${ }^{\text {TM }}$ trial investigators. Design of a randomised, placebo-controlled clinical trial of nintedanib in patients with systemic sclerosis-associated interstitial lung disease (SENSCIS ${ }^{\text {тM }}$ ). Clin Exp Rheumatol. 35 Suppl 106, 75-81 (2017).

138. http://www.clinicaltrials.gov/ct2/show/NCT02597933

139. Hsu VM, Denton CP, Domsic RT, Furst DE, Rischmueller M, Stanislav M, Steen VD, Distler JHW, Korish S, Cooper A, Choi S, Schafer PH, Horan G, Hough DR. Pomalidomide in Patients 
with Interstitial Lung Disease due to Systemic Sclerosis: A Phase II, Multicenter, Randomized, Double-blind, Placebo-controlled, Parallel-group Study. J Rheumatol. pii: jrheum.161040. doi: 10.3899/jrheum.161040. [Epub ahead of print] (2017).

140. Black CM, Silman AJ, Herrick AI, Denton CP, Wilson H, Newman J, Pompon L, Shi-Wen X. Interferon-alpha does not improve outcome at one year in patients with diffuse cutaneous scleroderma: results of a randomized, double-blind, placebo-controlled trial. Arthritis Rheum. 42, 299-305 (1999).

141. Seibold JR, Denton CP, Furst DE, Guillevin L, Rubin LJ, Wells A, Matucci Cerinic M, Riemekasten G, Emery P, Chadha-Boreham H, Charef P, Roux S, Black CM. Randomized, prospective, placebo-controlled trial of bosentan in interstitial lung disease secondary to systemic sclerosis. Arthritis Rheum. 62, 2101-8 (2010).

142. Volkmann ER, Chung A, Tashkin DP. Managing Systemic Sclerosis-Related Interstitial Lung Disease in the Modern Treatment Era. Journal of Scleroderma and Related Disorders. 2. 10.5301/jsrd.5000237. (2017).

143. Ghataorhe P, Rhodes CJ, Harbaum L, Attard M, Wharton J, Wilkins MR. Pulmonary arterial hypertension - progress in understanding the disease and prioritizing strategies for drug development. J Intern Med. 282, 129-141 (2017).

144. Badesch DB, Tapson VF, McGoon MD, Brundage BH, Rubin LJ, Wigley FM, Rich S, Barst RJ, Barrett PS, Kral KM, Jöbsis MM, Loyd JE, Murali S, Frost A, Girgis R, Bourge RC, Ralph DD, Elliott CG, Hill NS, Langleben D, Schilz RJ, McLaughlin VV, Robbins IM, Groves BM, Shapiro S, Medsger TA Jr. Continuous intravenous epoprostenol for pulmonary hypertension due to the scleroderma spectrum of disease. A randomized, controlled trial. Ann Intern Med. 132:425-34 (2000).

145. Badesch DB, McGoon MD, Barst RJ, Tapson VF, Rubin LJ, Wigley FM, Kral KM, Raphiou IH, Crater GD. Longterm survival among patients with scleroderma-associated pulmonary arterial hypertension treated with intravenous epoprostenol. J Rheumatol, 36, 2244-9 (2009).

146. Fischer A, Denton CP, Matucci-Cerinic M, Gillies H, Blair C, Tislow J, Nathan SD. Ambrisentan response in connective tissue disease-associated pulmonary arterial hypertension (CTDPAH) - A subgroup analysis of the ARIES-E clinical trial. Respir Med. 117:254-63 (2016).

147. Valerio CJ, Handler CE, Kabunga P, Smith CJ, Denton CP, Coghlan JG. Clinical experience with bosentan and sitaxentan in connective tissue disease-associated pulmonary arterial hypertension. Rheumatology (Oxford). 49, 2147-53 (2010).

148. Badesch DB, Hill NS, Burgess G, Rubin LJ, Barst RJ, Galiè N, Simonneau G; SUPER Study Group. Sildenafil for pulmonary arterial hypertension associated with connective tissue disease. J Rheumatol. 34, 2417-22 (2007).

149. Denton CP, Humbert M, Rubin L, Black CM. Bosentan treatment for pulmonary arterial hypertension related to connective tissue disease: a subgroup analysis of the pivotal clinicaltrials 144,145and their open-label extensions. Ann Rheum Dis. 65, 1336-40 (2006).

150. Pulido T, Adzerikho I, Channick RN, Delcroix M, Galiè N, Ghofrani HA, Jansa P, Jing ZC, Le Brun FO, Mehta S, Mittelholzer CM, Perchenet L, Sastry BK, Sitbon O, Souza R, Torbicki A, Zeng X, Rubin LJ, Simonneau G; SERAPHIN Investigators. Macitentan and morbidity and mortality in pulmonary arterial hypertension. N Engl J Med. 369, 809-18 (2013). 
151. Sitbon O, Channick R, Chin KM, Frey A, Gaine S, Galiè N, Ghofrani HA, Hoeper MM, Lang IM, Preiss R, Rubin LJ, Di Scala L, Tapson V, Adzerikho I, Liu J, Moiseeva O, Zeng X, Simonneau G, McLaughlin VV; GRIPHON Investigators. Selexipag for the Treatment of Pulmonary Arterial Hypertension. N Engl J Med. 373, 2522-33 (2015).

152. Galiè N, Barberà JA, Frost AE, Ghofrani HA, Hoeper MM, McLaughlin VV, Peacock AJ, Simonneau G, Vachiery JL, Grünig E, Oudiz RJ, Vonk-Noordegraaf A, White RJ, Blair C, Gillies $\mathrm{H}$, Miller KL, Harris JH, Langley J, Rubin LJ; AMBITION Investigators. Initial Use of Ambrisentan plus Tadalafil in Pulmonary Arterial Hypertension. N Engl J Med. 373, 834-44 (2015).

153. Hassoun PM, Zamanian RT, Damico R, Lechtzin N, Khair R, Kolb TM, Tedford RJ, Hulme OL, Housten T, Pisanello C, Sato T, Pullins EH, Corona-Villalobos CP, Zimmerman SL, Gashouta MA, Minai OA, Torres F, Girgis RE, Chin K, Mathai SC. Ambrisentan and Tadalafil Up-front Combination Therapy in Scleroderma-associated Pulmonary Arterial Hypertension. Am J Respir Crit Care Med. 192, 1102-10 (2015).

154. Coghlan JG, Galiè N, Barberà JA, Frost AE, Ghofrani HA, Hoeper MM, Kuwana M, McLaughlin VV, Peacock AJ, Simonneau G, Vachiéry JL, Blair C, Gillies H, Miller KL, Harris JHN, Langley J, Rubin LJ; AMBITION investigators. Initial combination therapy with ambrisentan and tadalafil in connective tissue disease-associated pulmonary arterial hypertension (CTD-PAH): subgroup analysis from the AMBITION trial. Ann Rheum Dis. 76, 1219-1227 (2017).

155. Gaine S, Chin K, Coghlan G, Channick R, Di Scala L, Galiè N, Ghofrani HA, Lang IM, McLaughlin V, Preiss R, Rubin LJ, Simonneau G, Sitbon O, Tapson VF, Hoeper MM. Selexipag for the treatment of connective tissue disease-associated pulmonary arterial hypertension. Eur Respir J. 50. pii: (2017).

156. Humbert M, Coghlan JG, Ghofrani HA, Grimminger F, He JG, Riemekasten G, Vizza CD, Boeckenhoff A, Meier C, de Oliveira Pena J, Denton CP. Riociguat for the treatment of pulmonary arterial hypertension associated with connective tissue disease: results from PATENT-1 and PATENT-2. Ann Rheum Dis. 76, 422-426 (2017).

157. Sitbon O, Jaïs X, Savale L, Cottin V, Bergot E, Macari EA, Bouvaist H, Dauphin C, Picard F, Bulifon S, Montani D, Humbert M, Simonneau G. Upfront triple combination therapy in pulmonary arterial hypertension: a pilot study. Eur Respir J. 43, 1691-7 (2014).

158. Launay D, Savale L, Berezne A, Le Pavec J, Hachulla E, Mouthon L, Sitbon O, Lambert B, Gaudric M, Jais X, Stephan F, Hatron PY, Lamblin N, Vignaux O, Cottin V, Farge D, Wallaert B, Guillevin L, Simonneau G, Mercier O, Fadel E, Dartevelle P, Humbert M, Mussot S; Working Group on Heart/Lung transplantation in systemic sclerosis of the French Network on Pulmonary Hypertension. Lung and heart-lung transplantation for systemic sclerosis patients. A monocentric experience of 13 patients, review of the literature and position paper of a multidisciplinary Working Group. Presse Med. 43(10 Pt 2):e345-63 (2014).

159. Miele CH, Schwab K, Saggar R, Duffy E, Elashoff D, Tseng CH, Weigt S, Charan D, Abtin F, Johannes J, Derhovanessian A, Conklin J, Ghassemi K, Khanna D, Siddiqui O, Ardehali A, Hunter C, Kwon M, Biniwale R, Lo M, Volkmann E, Torres Barba D, Belperio JA, Sayah D, Mahrer T, Furst DE, Kafaja S, Clements P, Shino M, Gregson A, Kubak B, Lynch JP 3rd, Ross D, Saggar R. Lung Transplant Outcomes in Systemic Sclerosis with Significant Esophageal Dysfunction. A Comprehensive Single-Center Experience. Ann Am Thorac Soc. 13, 793-802 (2016). 
160. Bernstein EJ, Peterson ER, Sell JL, D'Ovidio F, Arcasoy SM, Bathon JM, Lederer DJ. Survival of adults with systemic sclerosis following lung transplantation: a nationwide cohort study. Arthritis Rheumatol. 67, 1314-22 (2015).

161. Saggar R, Khanna D, Furst DE, Belperio JA, Park GS, Weigt SS, Kubak B, Ardehali A, Derhovanessian A, Clements PJ, Shapiro S, Hunter C, Gregson A, Fishbein MC, Lynch lii JP, Ross DJ, Saggar R. Systemic sclerosis and bilateral lung transplantation: a single centre experience. Eur Respir J. 36, 893-900 (2010).

162. Khan IY, Singer LG, de Perrot M, Granton JT, Keshavjee S, Chau C, Kron A, Johnson SR. Survival after lung transplantation in systemic sclerosis. A systematic review. Respir Med. 107:2081-7 (2013).

163. Herrick AL, Pan X, Peytrignet S, Lunt M, Hesselstrand R, Mouthon L, Silman A, Brown E, Czirják L, Distler JHW, Distler O, Fligelstone K, Gregory WJ, Ochiel R, Vonk M, Ancuţa C, Ong VH, Farge D, Hudson M, Matucci-Cerinic M, Balbir-Gurman A, Midtvedt $\varnothing$, Jordan AC, Jobanputra P, Stevens W, Moinzadeh P, Hall FC, Agard C, Anderson ME, Diot E, Madhok R, Akil M, Buch MH, Chung L, Damjanov N, Gunawardena H, Lanyon P, Ahmad Y, Chakravarty K, Jacobsen S, MacGregor AJ, McHugh N, Müller-Ladner U, Riemekasten G, Becker M, Roddy J, Carreira PE, Fauchais AL, Hachulla E, Hamilton J, Inanç M, McLaren JS, van Laar JM, Pathare S, Proudman S, Rudin A, Sahhar J, Coppere B, Serratrice C, Sheeran T, Veale DJ, Grange C, Trad GS, Denton CP. Treatment outcome in early diffuse cutaneous systemic sclerosis: the European Scleroderma Observational Study (ESOS). Ann Rheum Dis. 76, 1207-1218 (2017).

164. Domsic RT, Nihtyanova SI, Wisniewski SR, Fine MJ, Lucas M, Kwoh CK, Denton CP, Medsger TA Jr. Derivation and External Validation of a Prediction Rule for Five-Year Mortality in Patients With Early Diffuse Cutaneous Systemic Sclerosis. Arthritis Rheumatol. 68, 993-1003 (2016).

165. Domsic RT, Nihtyanova SI, Wisniewski SR, Fine MJ, Lucas M, Kwoh CK, Denton CP, Medsger TA Jr. Derivation and validation of a prediction rule for two-year mortality in early diffuse cutaneous systemic sclerosis. Arthritis Rheumatol. 66, 1616-24 (2014).

166. Kowal-Bielecka O, Fransen J, Avouac J, Becker M, Kulak A, Allanore Y, Distler O, Clements P, Cutolo M, Czirjak L, Damjanov N, Del Galdo F, Denton CP, Distler JHW, Foeldvari I, Figelstone $K$, Frerix M, Furst DE, Guiducci S, Hunzelmann N, Khanna D, Matucci-Cerinic M, Herrick AL, van den Hoogen F, van Laar JM, Riemekasten G, Silver R, Smith V, Sulli A, Tarner I, Tyndall A, Welling J, Wigley F, Valentini G, Walker UA, Zulian F, Müller-Ladner U; EUSTAR Coauthors. Update of EULAR recommendations for the treatment of systemic sclerosis. Ann Rheum Dis. 76, 1327-1339 (2017).

167. Hsu VM, Chung L, Hummers LK, Wigley F, Simms R, Bolster M, Silver R, Fischer A, Hinchcliff ME, Varga J, Goldberg AZ, Derk CT, Schiopu E, Khanna D, Shapiro LS, Domsic RT, Medsger T, Mayes MD, Furst D, Csuka ME, Molitor JA, Alkassab F, Steen VD. Development of pulmonary hypertension in a high-risk population with systemic sclerosis in the Pulmonary Hypertension Assessment and Recognition of Outcomes in Scleroderma (PHAROS) cohort study. Semin Arthritis Rheum. 44, 55-62 (2014).

168. Barst RJ, Langleben D, Badesch D, Frost A, Lawrence EC, Shapiro S, Naeije R, Galie N; STRIDE2 Study Group. Treatment of pulmonary arterial hypertension with the selective endothelinA receptor antagonist sitaxsentan. J Am Coll Cardiol. 47, 2049-56 (2006). 
169. Olschewski H, Simonneau G, Galiè N, Higenbottam T, Naeije R, Rubin LJ, Nikkho S, Speich R, Hoeper MM, Behr J, Winkler J, Sitbon O, Popov W, Ghofrani HA, Manes A, Kiely DG, Ewert R, Meyer A, Corris PA, Delcroix M, Gomez-Sanchez M, Siedentop H, Seeger W; Aerosolized Iloprost Randomized Study Group. Inhaled iloprost for severe pulmonary hypertension. N Engl J Med. 347, 322-9 (2002).

170. Hinchcliff M, Khanna S, Hsu VM, Lee J, Almagor O, Chang RW, Steen V, Chung L; PHAROS Investigators. Survival in systemic sclerosis-pulmonary arterial hypertension by serum autoantibody status in the Pulmonary Hypertension Assessment and Recognition of Outcomes in Scleroderma (PHAROS) Registry. Semin Arthritis Rheum. 45, 309-14 (2015).

171. Oudiz RJ, Schilz RJ, Barst RJ, Galié N, Rich S, Rubin LJ, Simonneau G; Treprostinil Study Group. Treprostinil, a prostacyclin analogue, in pulmonary arterial hypertension associated with connective tissue disease. Chest. 126, 420-7 (2004).

172. Fischer A, Denton CP, Matucci-Cerinic M, Gillies H, Blair C, Tislow J, Nathan SD. Ambrisentan response in connective tissue disease-associated pulmonary arterial hypertension (CTDPAH) - A subgroup analysis of the ARIES-E clinical trial. Respir Med. 117:254-63 (2016).

173. McLaughlin V, Channick RN, Ghofrani HA, Lemarié JC, Naeije R, Packer M, Souza R, Tapson VF, Tolson J, Al Hiti H, Meyer G, Hoeper MM. Bosentan added to sildenafil therapy in patients with pulmonary arterial hypertension. Eur Respir J. 46, 405-13 (2015).

\section{Author contributions}

All authors researched data for the article, provided substantial contributions to discussions of the content, wrote the article and reviewed and/or edited the article before submission.

\section{Competing interests}

C.P.D has received honoraria from Actelion, Bayer, Boehringer Ingelheim, Genentech-Roche, GSK. and consultancy fees from Actelion, Bayer, Boehringer Ingelheim, CSL Behring, Genentech-Roche, GSK, Inventiva, Merck-Serono, Sanofi-Aventis. A.U.W and J.G.C declare no competing interests. OK for CD. Others should submit own COI details of confirm no competing interests

\section{Publisher's note}

Springer Nature remains neutral with regard to jurisdictional claims in published maps and institutional affiliations.

\section{Key points}


- Lung complications are frequent in systemic sclerosis (SSc) and include lung fibrosis and pulmonary hypertension which have a substantial impact on disease outcomeand are both major causes of SSc-related death.

- Systematic valuation of patienst ensures that diagnosis of lung fibrosis and pulmonary hypertension is timely and permits treatment at earliest possible stage.

- There are multiple licensed therapies for pulmonary arterial hypertension and use of these agents alone and in combination has improved outcome and survival in event driven morbiditymortality trials.

- There are no approved therapies for lung fibrosis but treatment with immunosuppression appears beneficial in recent clinical trails and is recommended for appropriate cases with severe or progressive lung fibrosis.

\section{Box 1: Potential causes of dyspnoea in patients with systemic sclerosis}

\section{$\underline{\text { Parenchymal lung disease }}$}

- In addition to typical systemic sclerosis (SSc)-associated interstitial lung disease (ILD), some patients with overlap syndromes might present with patterns of lung involvement associated with other autoimmune rheumatic diseases [67], such as organizing pneumonia (a frequent feature in myositis [and airway involvement (seen in rheumatoid arthritis and Sjögren syndrome) [67].

\section{$\underline{\text { Respiratory comorbidities }}$}

- Comorbidities including smoking-related emphysema, infection and pulmonary thromboembolism can cause dyspnoea.

\section{Pulmonary vasculopathy}

- Pulmonary arterial hypertension (PAH) can present with exertional dyspnoea. In some patients, pulmonary vascular disease is not sufficiently severe to manifest as PAH at rest but can cause exertional dyspnoea owing to a loss of pulmonary vascular reserve [71]. [

\section{Cardiac involvement}

- Dyspnoea might be caused by systolic or more commonly diastolic dysfunction, rate or rhythm disturbances [5] or from pericardial effusion. Cardiac involvement is frequent in SSc but can be challenging to diagnose and is not always symptomatic [66]. 


\section{Cardiac comorbidities}

- Coronary heart disease and valvular heart disease (especially aortic stenosis) can cause dyspnoea and might be associated with angina, but dyspnoea without concurrent angina may reflect otherwise unsuspected cardiac comorbidity in some patients.

\section{Anaemia}

- This condition might arise from a variety of mechanisms and cause dyspnoea and might also aggravate other manifestation such as PAH [5].

\section{Arthritis}

- Arthropathy, owing to either autoimmune disease or concurrent osteoarthritis, can, in isolation, cause exertional dyspnoea because of the increased work of locomotion

\section{Muscle involvement}

- Peripheral muscle limitation because of autoimmune muscle involvement is an oftenunderestimated contributor to exercise limitation [167]

\section{Conditioning}

- Cardiorespiratory and musculoskeletal conditioning is a common cause of subjective exertional dyspnoea in SSc [5], which might be amplified if loss of fitness is associated with significant weight gain.

Box 2 Risk factors for severe lung fibrosis in systemic sclerosis [Au: Only one of these risk factors has a reference cited. Could you provide references for the other risk factors listed here?]

- Diffuse cutaneous systemic sclerosis [50]

- Less than 3 years disease duration [50]

- Severe gastro-oesophageal reflux [22, 23]

- The presence of antinuclear antibodies (in particular anti-topoisomerase-1 antinuclear antibodies, but also anti-Th/To ribonucleoprotein (RNP) antibodies or anti-U11/U12 RNP antibodies) [94]

- A 'severe' score by the UK-RSA Staging system [96]

- Declining lung function [50]

- Evidence of epithelial damage (for example, elevated KL-6 or fast DTPA clearance) [25] 


\begin{tabular}{|c|c|c|c|c|c|}
\hline $\begin{array}{l}\text { WHO } \\
\text { Group }\end{array}$ & $\begin{array}{l}\text { Designation for } \\
\text { management }\end{array}$ & Investigation and diagnosis & Approximate frequency in SSc & Treatment considerations & Features \\
\hline I & $\begin{array}{l}\text { Precapillary } \\
\text { pulmonary arterial } \\
\text { hypertension (PAH) }\end{array}$ & $\begin{array}{l}\text { PAH is defined by } \mathrm{mPAP} \geq \\
25 \mathrm{~mm} \mathrm{Hg} \text { with PAWP } \leq 15 \\
\mathrm{~mm} \mathrm{Hg} \text { and PVR } \geq 3 \mathrm{WU} \\
\text { without major lung fibrosis }\end{array}$ & $\begin{array}{l}\text { PAH is the most common cause of } \\
\text { severe pulmonary hypertension in } \\
\text { SSc and probably accounts for } \\
\sim 60 \% \text { of patients with SSc- } \\
\text { associated pulmonary hypertension } \\
\text { [77] }\end{array}$ & $\begin{array}{l}\text { Supportive measures and targeted PAH } \\
\text { specific medication can be given, often } \\
\text { in combination }\end{array}$ & $\begin{array}{l}\text { Borderline elevation of mPAP ( } 21-14 \\
\mathrm{~mm} \mathrm{Hg}) \text { is associated with high risk of } \\
\text { developing established PAH [82] }\end{array}$ \\
\hline$l^{\prime}$ & $\begin{array}{l}\text { Pulmonary veno- } \\
\text { occlusive disease } \\
\text { (PVOD) }\end{array}$ & $\begin{array}{l}\text { PVOD has a similar } \\
\text { haemodynamics to PAH but } \\
\text { presents with CT findings of } \\
\text { septal lines, nodules and } \\
\text { lymphadenopathy }\end{array}$ & $\begin{array}{l}\text { The frequency of PVOD in SSc is } \\
\text { unknown but up to } 15 \% \text { of patients } \\
\text { with SSc-associated pulmonary } \\
\text { hypertension might have elements } \\
\text { of PVOD [61]. PVOD is rarely } \\
\text { observed as the pure cause of } \\
\text { pulmonary hypertension }\end{array}$ & $\begin{array}{l}\text { Supportive measures and vasodilator } \\
\text { therapy can be used but the latter } \\
\text { should be used with care as this } \\
\text { therapy might otherwise precipitate } \\
\text { pulmonary oedema } \\
\text { Immunosuppressive therapy might be } \\
\text { beneficial for some patients. }\end{array}$ & $\begin{array}{l}\text { The frequency of apparent PVOD } \\
\text { varies between cohort studies and } \\
\text { some patients might have both PVOD } \\
\text { and Group I PAH }[60,61] \text {. }\end{array}$ \\
\hline II & $\begin{array}{l}\text { Post-capillary } \\
\text { pulmonary } \\
\text { hypertension }\end{array}$ & $\begin{array}{l}\text { Group II pulmonary } \\
\text { hypertension is } \\
\text { characterized by elevated } \\
\text { PAWP above } 15 \mathrm{~mm} \mathrm{Hg} \text { in } \\
\text { association with pulmonary } \\
\text { hypertension mPAP > } 25 \\
\mathrm{~mm} \mathrm{Hg}\end{array}$ & $\begin{array}{l}\text { In } \sim 15 \% \text { of patients with SSc- } \\
\text { associated pulmonary } \\
\text { hypertension, group II pulmonary } \\
\text { hypertension is the major form [77] } \\
\text { However, the frequency of group II } \\
\text { pulmonary hypertension is difficult } \\
\text { to determine. In the context of } \\
\text { scleroderma renal crisis with } \\
\text { systemic hypertension, this form is } \\
\text { the most likely explanation for } \\
\text { concurrent pulmonary } \\
\text { hypertension and might later } \\
\text { improve without specific therapy. }\end{array}$ & $\begin{array}{l}\text { The cardiac cause (including systolic or } \\
\text { diastolic failure, arrhythmia and } \\
\text { valvular disease) should be treated. In } \\
\text { some patients, vasodilator therapy } \\
\text { with PAH specific therapies might be } \\
\text { considered but these therapies might } \\
\text { worsen heart failure and so need to be } \\
\text { used with some caution. }\end{array}$ & $\begin{array}{l}\text { The true frequency of this form of } \\
\text { hypertension is unclear, and some } \\
\text { studies suggest that there is often a } \\
\text { post-capillary component to } \\
\text { pulmonary hypertension in SSc, } \\
\text { which might be apparent with a fluid } \\
\text { challenge at right heart } \\
\text { catheterisation. This form might } \\
\text { sometimes co-exist with Group I PAH } \\
\text { [66] }\end{array}$ \\
\hline III & $\begin{array}{l}\text { Pulmonary } \\
\text { hypertension owing } \\
\text { to lung fibrosis or } \\
\text { hypoxia }\end{array}$ & $\begin{array}{l}\text { In SSc, this form of } \\
\text { pulmonary hypertension is } \\
\text { difficult to classify as many } \\
\text { patients have some degree } \\
\text { of lung fibrosis. A diagnosis } \\
\text { of pulmonary hypertension }\end{array}$ & $\begin{array}{l}\text { Approximately } 15 \% \text { of patients with } \\
\text { SSc-associated pulmonary } \\
\text { hypertension are estimated to have } \\
\text { Group III pulmonary hypertension }\end{array}$ & $\begin{array}{l}\text { Treatment of any associated chest wall } \\
\text { skin fibrosis, myositis and lung fibrosis } \\
\text { should be prioritized. Subsequently, } \\
\text { judicious use of vasodilator therapy } \\
\text { might be considered, but should be } \\
\text { used with caution as this therapy might }\end{array}$ & $\begin{array}{l}\text { Lung fibrosis occurs in over } 50 \% \text { of } \\
\text { patients of SSc and so fibrosis often } \\
\text { co-exists with other forms of } \\
\text { pulmonary hypertension. Therefore, } \\
\text { simply demonstrating the presence } \\
\text { of any lung fibrosis is not usually }\end{array}$ \\
\hline
\end{tabular}




\begin{tabular}{|c|c|c|c|c|c|}
\hline & & $\begin{array}{l}\text { associated with lung } \\
\text { fibrosis is normally made if } \\
\text { specified thresholds of } \\
\text { various tests of lung } \\
\text { function are exceeded: for } \\
\text { example, }>70 \% \text { predicted } \\
\text { FVC (by spirometry) or } \\
>20 \% \text { fibrotic lung volume } \\
\text { involvement (by HRCT) }\end{array}$ & & $\begin{array}{l}\text { aggravate hypoxia owing to a } \\
\text { decreased ventilation to perfusion } \\
\text { ratio }\end{array}$ & $\begin{array}{l}\text { sufficient for classifying patients into } \\
\text { this group [52]. }\end{array}$ \\
\hline IV & $\begin{array}{l}\text { Thrombo-embolic } \\
\text { pulmonary } \\
\text { hypertension }\end{array}$ & $\begin{array}{l}\text { All patients with suspected } \\
\text { PAH should be investigated } \\
\text { to exclude chronic } \\
\text { thromboembolic disease as } \\
\text { this form of pulmonary } \\
\text { hypertension can be } \\
\text { treated surgically. }\end{array}$ & $\begin{array}{l}\text { Research studies suggest that intra } \\
\text { vascular thrombosis is present in } \\
\text { some cases of SSc-associated PAH } \\
\text { but others develop more typical } \\
\text { CTEPH [58]. }\end{array}$ & $\begin{array}{l}\text { The management of thrombo-embolic } \\
\text { disease should be in line with current } \\
\text { recommendations and includes surgical } \\
\text { treatment, medical therapy and, when } \\
\text { suitable, balloon pulmonary } \\
\text { angioplasty. Routine use of } \\
\text { anticoagulants in PAH in SSc is not } \\
\text { associated with better outcome and so } \\
\text { is not recommended. }\end{array}$ & $\begin{array}{l}\text { This is uncommon as a major cause } \\
\text { of pulmonary hypertension in SSc but } \\
\text { mural thrombosis (a thrombosis that } \\
\text { partially blocks the blood vessel) } \\
\text { might be observed in vessels by } \\
\text { imaging [58]. }\end{array}$ \\
\hline $\mathrm{V}$ & $\begin{array}{l}\text { Uncommon and } \\
\text { multifactorial } \\
\text { pulmonary } \\
\text { hypertension }\end{array}$ & $\begin{array}{l}\text { Routine pulmonary } \\
\text { hypertension investigation } \\
\text { supplemented with } \\
\text { extensive additional tests } \\
\text { should be used to confirm } \\
\text { multifactorial and/or } \\
\text { uncommon causes }\end{array}$ & $\begin{array}{l}\text { Rare causes of pulmonary } \\
\text { hypertension might co-exist with } \\
\text { SSc. In addition, individuals with } \\
\text { pulmonary hypertension arising } \\
\text { from multiple mechanisms might } \\
\text { be considered as part of this group }\end{array}$ & $\begin{array}{l}\text { Type } V \text { pulmonary hypertension is a } \\
\text { heterogeneous group that includes } \\
\text { forms with various mechanisms and } \\
\text { pathologies and so the frequency will } \\
\text { depend on what definition of } \\
\text { mechanisms thatare included in this } \\
\text { group. }\end{array}$ & $\begin{array}{l}\text { Patients might have pulmonary } \\
\text { hypertension with multifactorial } \\
\text { elements but usually one of these } \\
\text { factors predominates }\end{array}$ \\
\hline
\end{tabular}

FVC, forced vital capacity; HRCT, high-resolution CT; mPAP, mean resting pulmonary arterial pressure; PAWP, pulmonary arterial wedge pressure; PVR, pulmonary vascular resistance; SSc, systemic sclerosis 


\begin{tabular}{|c|c|c|c|c|}
\hline Drug & Delivery route & $\begin{array}{l}\text { Evidence for efficacy in SSc-associated PAH [Au: For this } \\
\text { column, could you please clarify on the findings of } \\
\text { the studies presenting this evidence, and provide } \\
\text { references] }\end{array}$ & Major adverse effects & Comments \\
\hline \multicolumn{5}{|c|}{ Endothelin receptor antagonists } \\
\hline Bosentan & Oral & $\begin{array}{l}\text { Similar treatment effect seen in SSc subgroup to the } \\
\text { overall treatment cohort in pivotal trials }\end{array}$ & $\begin{array}{l}\text { Abnormal liver function tests, } \\
\text { anaemia, oedema and nasal } \\
\text { congestion }\end{array}$ & $\begin{array}{l}\text { The first oral therapy licensed } \\
\text { for SSc-associated PAH. } \\
\text { Anecdotal improvement in long } \\
\text { term outcome and preventing } \\
\text { mortality [149] }\end{array}$ \\
\hline Ambrisentan & Oral & $\begin{array}{l}\text { Similar treatment effect seen in SSc subgroup to the } \\
\text { overall treatment cohort in pivotal trials and ambrisentan } \\
\text { in combination with tadalafil is highly efficacious }\end{array}$ & $\begin{array}{l}\text { Anaemia, oedema, fluid } \\
\text { retention and nasal congestion }\end{array}$ & $\begin{array}{l}\text { Fewer drug interactions than } \\
\text { other endothelin receptor } \\
\text { antagonists [146] }\end{array}$ \\
\hline Macitentan & Oral & $\begin{array}{l}\text { Demonstrated high efficacy compared with placebo in a } \\
\text { robust outcome study using morbidity-mortality } \\
\text { endpoint. }\end{array}$ & Anaemia and nasal congestion. & $\begin{array}{l}\text { Macitentan in combination with } \\
\text { a PDE5 inhibitor is also highly } \\
\text { efficacious [150] }\end{array}$ \\
\hline \multicolumn{5}{|c|}{ Prostacyclin pathway targeting therapies } \\
\hline Beraprost* & Oral & No robust efficacy data available & $\begin{array}{l}\text { Jaw pain, diarrhoea, } \\
\text { hypotension and headache }\end{array}$ & $\begin{array}{l}\text { Not licensed in Europe or North } \\
\text { America. }\end{array}$ \\
\hline Selexipag* & Oral & $\begin{array}{l}\text { Robust long-term data from Griphon trial including cases } \\
\text { on triple therapy with an endothelin receptor antagonist } \\
\text { and PDE5 inhibitor. There was benefit in morbidity- } \\
\text { mortality for cases treated with selexipag compared with } \\
\text { placebo, even in cases already on dual combination } \\
\text { therapy [151]. }\end{array}$ & $\begin{array}{l}\text { Jaw pain, diarrhoea, } \\
\text { hypotension and headache }\end{array}$ & $\begin{array}{l}\text { Also licensed for CTEPH. Cannot } \\
\text { be combined with a PDE5 } \\
\text { inhibitor [151] }\end{array}$ \\
\hline
\end{tabular}




\begin{tabular}{|c|c|c|c|c|}
\hline Epoprostenol** & Intravenous & $\begin{array}{l}\text { Demonstrated efficacy in a randomized open label study } \\
\text { but no mortality benefit reported }\end{array}$ & $\begin{array}{l}\text { Line sepsis, jaw pain, diarrhoea, } \\
\text { hypotension, headache and } \\
\text { rapid worsening if infusion } \\
\text { interrupted }\end{array}$ & $\begin{array}{l}\text { Epoprostenol is generally used } \\
\text { in patients with severe } \\
\text { pulmonary hypertension, } \\
\text { particularly patients with class } \\
\text { IV pulmonary hypertension [] }\end{array}$ \\
\hline lloprost** & Inhaled & $\begin{array}{l}\text { Similar treatment effect seen in SSc subgroup to the } \\
\text { overall treatment cohort in pivotal trials [167]. }\end{array}$ & $\begin{array}{l}\text { Jaw pain, diarrhoea, } \\
\text { hypotension and headache }\end{array}$ & $\begin{array}{l}\text { Inhaled route not popular with } \\
\text { many patients but other } \\
\text { formulations not approved } \\
\text { [169] }\end{array}$ \\
\hline Treprostinil** & $\begin{array}{l}\text { Subcutaneous } \\
\text { or intravenous }\end{array}$ & $\begin{array}{l}\text { Similar treatment effect seen in SSc subgroup to the } \\
\text { overall treatment cohort in pivotal trials [OLD 163]. }\end{array}$ & $\begin{array}{l}\text { Injection site pain (from } \\
\text { subcutaneous administration), } \\
\text { jaw pain, diarrhoea, } \\
\text { hypotension and headache }\end{array}$ & $\begin{array}{l}\text { Pain at site of injection is a } \\
\text { major limitation [171] }\end{array}$ \\
\hline \multicolumn{5}{|l|}{ PDE5 inhibitors } \\
\hline Sildenafil & Oral & $\begin{array}{l}\text { Improved exercise capacity for SSc as in overall treatment } \\
\text { groups in pivotal trial [148] }\end{array}$ & $\begin{array}{l}\text { Hypotension, interaction with } \\
\text { nitrates, visual disturbance, } \\
\text { epistaxis, headache and } \\
\text { priapism }\end{array}$ & $\begin{array}{l}\text { Sildenafil is a widely use first } \\
\text { line therapy and the generic } \\
\text { formulation is relatively } \\
\text { inexpensive. This therapy is } \\
\text { often used in combination with } \\
\text { an endothelin receptor } \\
\text { antagonist [148] }\end{array}$ \\
\hline Tadalafil & Oral & $\begin{array}{l}\text { Improved exercise capacity for SSc similar to overall } \\
\text { treatment groups in pivotal trial [154] }\end{array}$ & $\begin{array}{l}\text { Hypotension, interaction with } \\
\text { nitrates, visual disturbance, } \\
\text { epistaxis, headache and } \\
\text { priapism }\end{array}$ & $\begin{array}{l}\text { Evidence base from studies } \\
\text { including in combination, most } \\
\text { robustly from the Ambition } \\
\text { clinical trial [153] }\end{array}$ \\
\hline \multicolumn{5}{|c|}{ Soluble guanylate cyclase agonist } \\
\hline Riociguat & Oral & $\begin{array}{l}\text { Data for SSc are in line with overall treatment groups in } \\
\text { pivotal trial showing benefit of active treatment } \\
\text { compared with placebo [156] }\end{array}$ & $\begin{array}{l}\text { Hypotension, epistaxis, } \\
\text { headache and haemoptysis }\end{array}$ & $\begin{array}{l}\text { This therapy has the theoretical } \\
\text { advantage of not depending } \\
\text { upon endothelial production of } \\
\text { nitric oxide for efficacy (unlike }\end{array}$ \\
\hline
\end{tabular}




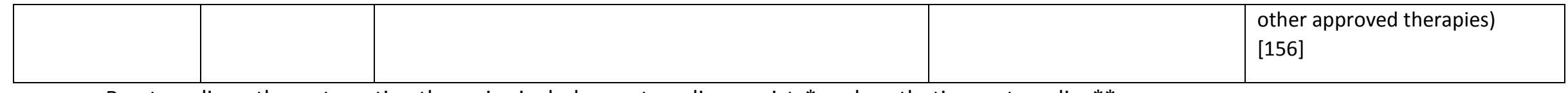

Prostacyclin pathway targeting therapies include prostacyclin agonists* and synthetic prostacyclins**

CTED, chronic thromboembolic disease; PDE5, phosphodiesterase type 5 inhibitor 
Table 3 Clinical trials of therapies in PAH that have included patients with SSC

\begin{tabular}{|c|c|c|c|c|c|c|}
\hline $\begin{array}{l}\text { Treatment (trial } \\
\text { name) }\end{array}$ & $\begin{array}{l}\text { Primary } \\
\text { endpoint }\end{array}$ & $\begin{array}{l}\text { Total } \\
\text { number of } \\
\text { patients } \\
\text { enrolled }\end{array}$ & $\begin{array}{l}\text { Number of } \\
\text { patients with } \\
\text { CTD- } \\
\text { associated } \\
\text { PAH (\%) }\end{array}$ & $\begin{array}{l}\text { Patients with SSc- } \\
\text { associated PAH (\%) }\end{array}$ & $\begin{array}{l}\text { Summary of resuts relevant to SSc } \\
\text { associated PAH }\end{array}$ & Reference \\
\hline \multicolumn{7}{|c|}{ Endothelin receptor antagonists } \\
\hline $\begin{array}{l}\text { Bosentan } \\
\text { (BREATHE-1 and } \\
\text { study 351) }\end{array}$ & SMWT & 245 & $66(27 \%)$ & $52(79 \%)$ & $\begin{array}{l}\text { These two pivotal trials in PAH led } \\
\text { to approval of bosentan and } \\
\text { included cases with SSc associated } \\
\text { PAH that had qualitatively similar } \\
\text { treatment benefit to overall cohort }\end{array}$ & 149 \\
\hline $\begin{array}{l}\text { Sitaxentan } \\
\text { (STRIDE-1 and } \\
\text { STRIDE-2) }\end{array}$ & SMWT & 425 & $110(26 \%)$ & $63(57 \%)$ & $\begin{array}{l}\text { These two trials confirmed } \\
\text { increase in SMWT in PAH cases } \\
\text { treated with sitaxentan including } \\
\text { those with SSc. Sitaxentan later } \\
\text { withdrawn due to hepatotoxicity }\end{array}$ & 168 \\
\hline $\begin{array}{l}\text { Ambrisentan } \\
\text { (ARIES-1 and } \\
\text { ARIES-2) }\end{array}$ & SMWT & 384 & $117(30 \%)$ & $76(65 \%)$ & $\begin{array}{l}\text { Both trials showed improved } \\
\text { SMWT in PAH treated with } \\
\text { ambrisentan compared with } \\
\text { placebo. Similar benefit in SSc } \\
\text { cases to overall cohort }\end{array}$ & 172 \\
\hline $\begin{array}{l}\text { Macitentan } \\
\text { (SERAPHIN) }\end{array}$ & $\begin{array}{l}\text { Morbidity and } \\
\text { mortality }\end{array}$ & 742 & $\begin{array}{l}224 \\
(30 \%)\end{array}$ & NS & $\begin{array}{l}\text { The first event driven morbidity- } \\
\text { mortality trial showed that adding } \\
\text { macitenan to background therapy }\end{array}$ & 150 \\
\hline
\end{tabular}




\begin{tabular}{|c|c|c|c|c|c|c|}
\hline & & & & & $\begin{array}{l}\text { or as first line treatment was } \\
\text { superior to placebo. Umerically } \\
\text { similar benefit for SSc-PAH to } \\
\text { overall cohort }\end{array}$ & \\
\hline \multicolumn{7}{|l|}{ PDE5 inhibitor } \\
\hline $\begin{array}{l}\text { Sildenafil } \\
\text { (SUPER-1) }\end{array}$ & SMWT & 278 & $\begin{array}{l}84 \\
(30 \%)\end{array}$ & $38(45 \%)$ & $\begin{array}{l}\text { Significant improvement in SMWT } \\
\text { for sildenafil treated PAH } \\
\text { compared with placebo and similar } \\
\text { effect in SSc-PAH to overall cohort }\end{array}$ & 148 \\
\hline \multicolumn{7}{|c|}{ Soluble guanylate cyclase agonist } \\
\hline $\begin{array}{l}\text { Riociguat } \\
\text { (PATENT-1, and } \\
\text { PATENT-2) }\end{array}$ & SMWT & 443 & $\begin{array}{l}96 \\
(22 \%)\end{array}$ & $59(61 \%)$ & $\begin{array}{l}\text { Improved SMWT distance in PAH } \\
\text { cases treated with riociguat } \\
\text { compared with placebo, including } \\
\text { those on background ERA. } \\
\text { Numerically smaller gain in PAH- } \\
\text { SSc but good long term survival in } \\
\text { all PAH }\end{array}$ & 156 \\
\hline \multicolumn{7}{|c|}{ Prostacyclin pathway targeting therapies } \\
\hline Epoprostenol $^{b}$ & SMWT & 111 & $\begin{array}{l}111 \\
(100 \%)\end{array}$ & $111(100 \%)$ & $\begin{array}{l}\text { Open label study showed gain in } \\
\text { exercise capacity (SMWT) but no } \\
\text { mortality benefit. }\end{array}$ & 144,145 \\
\hline Treprostinil $^{\mathrm{C}}$ & SMWT & 470 & $\begin{array}{l}90 \\
(19 \%)\end{array}$ & NS & $\begin{array}{l}\text { Significant improvement in SMWT } \\
\text { for subcutaneous treprostinil } \\
\text { treated PAH compared with } \\
\text { placebo and similar effect in SSc- } \\
\text { PAH to overall cohort }\end{array}$ & 171 \\
\hline
\end{tabular}




\begin{tabular}{|c|c|c|c|c|c|c|}
\hline Iloprost $^{\mathrm{C}}$ (AIR) & SMWT & 203 & $35(17 \%)$ & NS & $\begin{array}{l}\text { Numerical gain in SMWT in active } \\
\text { treatment compared with placebo } \\
\text { but not reaching statistical } \\
\text { significance. }\end{array}$ & 169 \\
\hline $\begin{array}{l}\text { Selexipag }^{\mathrm{b}} \\
\text { (GRIPHON) }\end{array}$ & $\begin{array}{l}\text { Morbidity and } \\
\text { mortality }\end{array}$ & 1156 & $334(29 \%)$ & $170(51 \%)$ & $\begin{array}{l}\text { Largest event driven morbidity- } \\
\text { mortality trial performed t date } \\
\text { showed that adding selexipag to } \\
\text { background therapy or as first line } \\
\text { treatment was superior to placebo. } \\
\text { Numerically similar benefit for SSc- } \\
\text { PAH to overall cohort }\end{array}$ & 151 \\
\hline \multicolumn{7}{|c|}{ Combined therapy with an endothelin receptor antagonist and phosphodiesterase type 5 inhibitor } \\
\hline $\begin{array}{l}\text { Bosentan added } \\
\text { to sildenafil } \\
\text { (COMPASS-2) }\end{array}$ & $\begin{array}{l}\text { Morbidity and } \\
\text { mortality }\end{array}$ & 334 & NS & NS & $\begin{array}{l}\text { No evidence of significant benefit } \\
\text { for combining sildenafil and } \\
\text { bosentan compared with sildenafil } \\
\text { alone }\end{array}$ & 172 \\
\hline $\begin{array}{l}\text { Ambrisentan and } \\
\text { tadalafil } \\
\text { (AMBITION) }\end{array}$ & $\begin{array}{l}\text { Morbidity and } \\
\text { mortality }\end{array}$ & 500 & $187(37 \%)$ & $118(63 \%)$ & $\begin{array}{l}\text { Important study demonstrating } \\
\text { that initial combination therapy } \\
\text { was superior to either single } \\
\text { treatment in PAH including PAH } \\
\text { due to SSc and significant benefit } \\
\text { was equivalent for SSc and non-SSC } \\
\text { cases including idiopathic PAH }\end{array}$ & 154 \\
\hline
\end{tabular}

${ }^{\mathrm{a}}$ Range indicates separate values for ARIES-1 and ARIES-2 trials Prostacyclin pathway targeting therapies include prostacyclin agonists ${ }^{\mathrm{b}}$ and synthetic prostacyclins ${ }^{c}$.

AIR, Aerosolized lloprost Randomized; AMBITION, Ambrisentan and Tadalafil in Patients with Pulmonary Arterial Hypertension; ARIES, Ambrisentan in Patients with Moderate to Severe Pulmonary Arterial Hypertension; BREATHE, Bosentan: Randomised Trial of Endothelin 
Receptor antagonist Therapy for Pulmonary Arterial Hypertension; COMPASS, Combination Therapy in Pulmonary Arterial Hypertension; GRIPHON, Prostacyclin (PGI2) Receptor Agonist In Pulmonary Arterial Hypertension; NS, not specified in the trial report; PATENT, Pulmonary Arterial Hypertension Soluble Guanylate Cyclase-Stimulator Trial; PDE5, phosphodiesterase type 5 inhibitor; SERAPHIN, Study with an Endothelin Receptor Antagonist in Pulmonary Arterial Hypertension to Improve Clinical Outcome; SMWT, six minute walk test; STRIDE, Sitaxsentan To Relieve Impaired Exercise in Pulmonary Arterial Hypertension; SUPER, Sildenafil Use in Pulmonary Arterial Hypertension 


\section{Figure 1 Pathogenesis of major lung complications in systemic sclerosis}

Multiple cell types and mediators are probably involved in the pathogenesis of lung fibrosis and pulmonary arterial hypertension. Tissue damage initiated by epithelial injury or inflammation might result in a local environment within the lung parenchyma that results in the generation and persistence of myofibroblasts. Accumulation of excess extracellular matrix and destruction of the lung structure in the absence of repair and regeneration can most often lead to a NSIP pattern of lung disease. In the pulmonary circulation, endothelial damage might promote a proliferative vascular response that includes multiple cell types and results in endoluminal lesions and medial wall thickening. Vascular fibrosis and perivascular inflammation can subsequently occur. The pathogenic processes that occur following epithelial injury (leading to lung fibrosis) and pulmonary endothelial injury (triggering pulmonary arterial hypertension) seem to be shared. Hence, SSc might be a susceptibility phenotype for these complications and other facets of the disease process, and autoimmune, genetic or environment factors might determine which of the potential manifestations is predominant.

\section{Figure 2 Screening for pulmonary hypertension in systemic sclerosis}

This schematic is an example of one approach for diagnosing and screening patients with pulmonary hypertension, and is in line with current recommendations for the diagnosis and management of such patients $[71,76]$. All patients with systemic sclerosis (SSC) should have an initial assessment looking at clinical features, lung function (including measures of diffusing capacity for carbon monoxide (DLCO)) and transthoracic echocardiographic findings. The abundance of $\mathrm{N}$-terminal pro-brain natriuretic peptide (Nt-pro BNP) should also be measured. For patients with a DLCO $<60 \%$ and disease duration of $>3$ years, the DETECT score can be calculated [77]. These tests are repeated annually in all patients, and if a patient develops clinical features suggestive of possible new pulmonary hypertension these tests are repeated more often. If the results (from either the transthoracic echocardiographic findings, pulmonary function tests or DETECT score) exceed defined thresholds, right heart catheterization should be performed to confirm a diagnosis of pulmonary hypertension. A diagnosis of pulmonary arterial hypertension (PAH) requires a low pulmonary arterial wedge pressure (PAWP) and the absence of major lung fibrosis (which would otherwise be classified as group III pulmonary hypertension).

FVC, forced vital capacity; mPAP, meaning resting pulmonary arterial pressure;

\section{Figure 3 Histological and CT appearances of major lung complications in systemic sclerosis}

The most common histological pattern of lung fibrosis in SSc is NSIP, which might be mild (part a) or extensive (part $b$ ) and is characterized by relative preservation of lung architecture and often a homogeneous "ground glass" change within the lungs (GC arrow). NSIP might have cellular or fibrotic subtypes. By contrast, compared with NSIP, the less common UIP pattern of fibrosis (part c) has a much more altered architecture, a more variable severity of fibrotic lesions and a less homogeneous pattern with dense fibrosis and cystic changes, termed honeycombing ( $\mathrm{HC}$ arrow). Pulmonary hypertension (part d) is characterized by enlargement of the pulmonary artery on CT imaging (PA arrow). A designation of PAH can only be made if only mild lung fibrosis is present as otherwise a classification of group III 
pulmonary hypertension is made. It is also important to note whether CT features of pulmonary venoocclusive disease (PVOD) are present such as septal lines, nodules or lymphadenopathy (not shown).

\section{Glossary terms}

Dyspnoea. Breathlessness that is a major symptom of lung complications in systemic sclerosis but that also has other potential causes including cardiac disease, anaemia and deconditioning.

Exertional dyspnoea. Subjective breathlessness that occurs on exertion and is a cardical feature of significant lung complications including lung fibrosis and pulmonary hypertension.

Fibroblasts. Cells that produce extracellular matrix and that are activated inappropriately or excelssively in fibrotic disease.

Myofibroblasts. Activated fibroblastic cells that have a contractile cytoskeleton that includes microfibrils containing alpha smooth muscle actin.

lung function test. Collective term for the physiological measurement of lung volume, airways resistance and gas exchange in the lungs. 


\section{Online only}

\section{Competing interests}

C.P.D has received honoraria from Actelion, Bayer, Boehringer Ingelheim, Genentech-Roche, GSK. or and consultancy fees from Actelion, Bayer, Boehringer Ingelheim, CSL Behring, Genentech-Roche, GSK, Inventiva, Merck-Serono, Sanofi-Aventis.

\section{Subject ontology terms}

Health sciences / Diseases / Rheumatic diseases / Connective tissue diseases / Systemic sclerosis [URI /692/699/1670/122/1801]

Health sciences / Diseases / Respiratory tract diseases

[URI /692/699/1785]

Health sciences / Pathogenesis

[URI /692/420]

Health sciences / Health care / Therapeutics

[URI /692/700/565]

Health sciences / Health care / Diagnosis

[URI /692/700/139]

\section{Table of contents blurb}

\section{Major lung complications of systemic sclerosis}

Christopher P. Denton, Athol U. Wells and John G. Coghlan

The two major lung complications in systemic sclerosis, lung fibrosis and pulmonary arterial hypertension, share some pathogenic mechanisms. Strategies for managing patients with these complications has greatly advanced in the past decade and many tools and treatments are now available. 

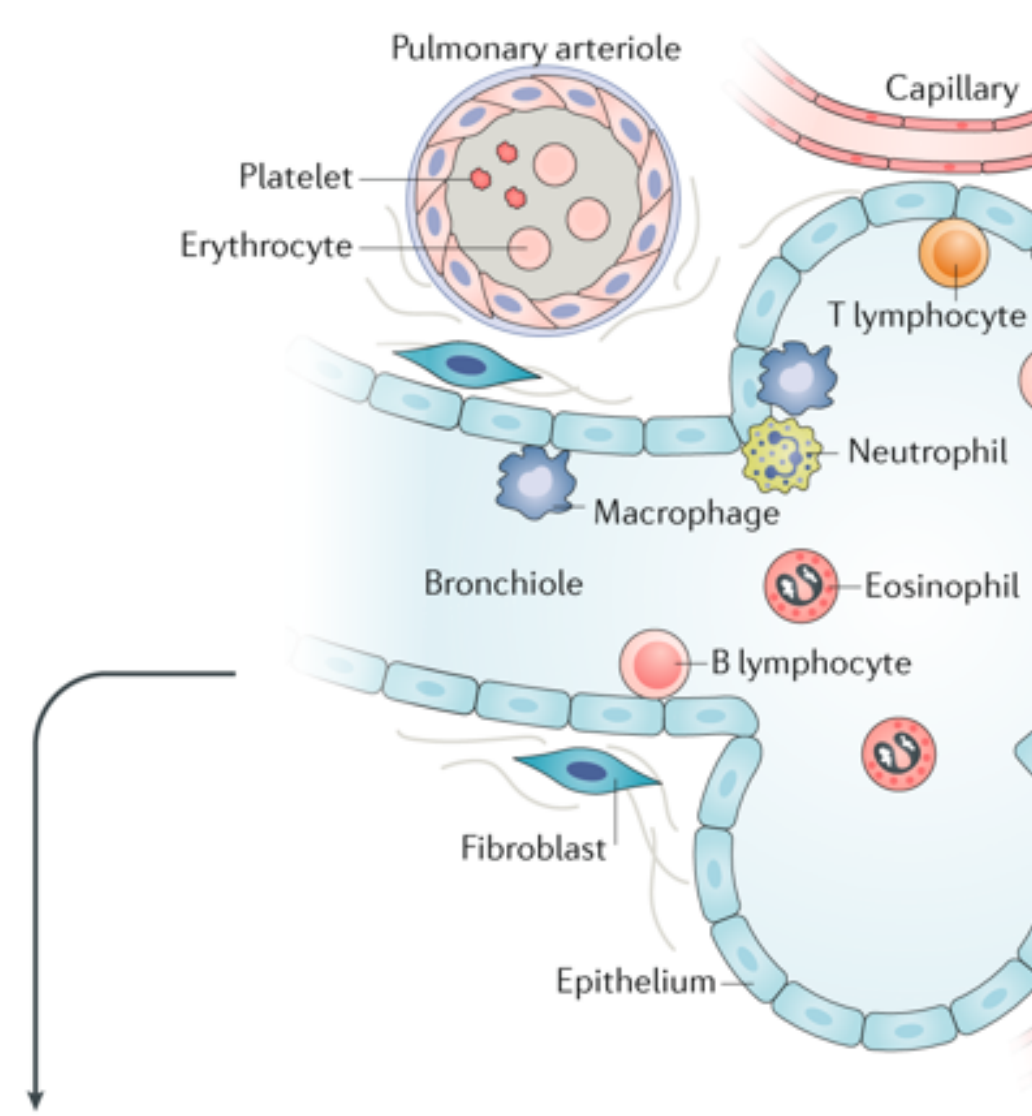

(3) Eosinophil

Bronchiole

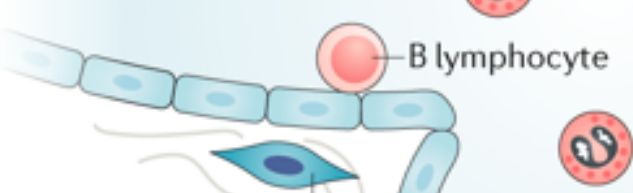

Fibroblast

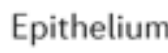

(2)

\section{Lung fibrosis}

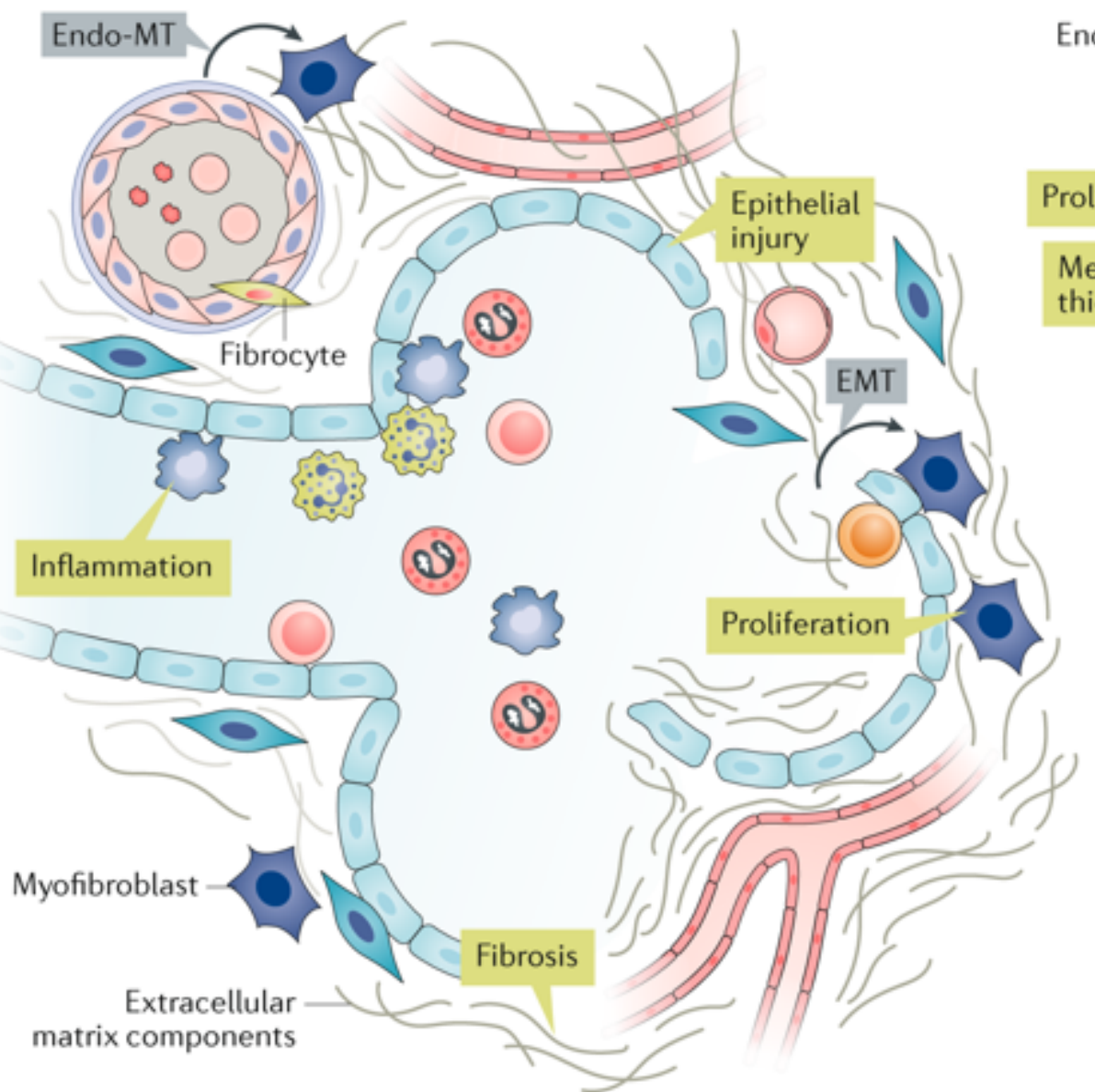

Pulmonary arterial hypertension

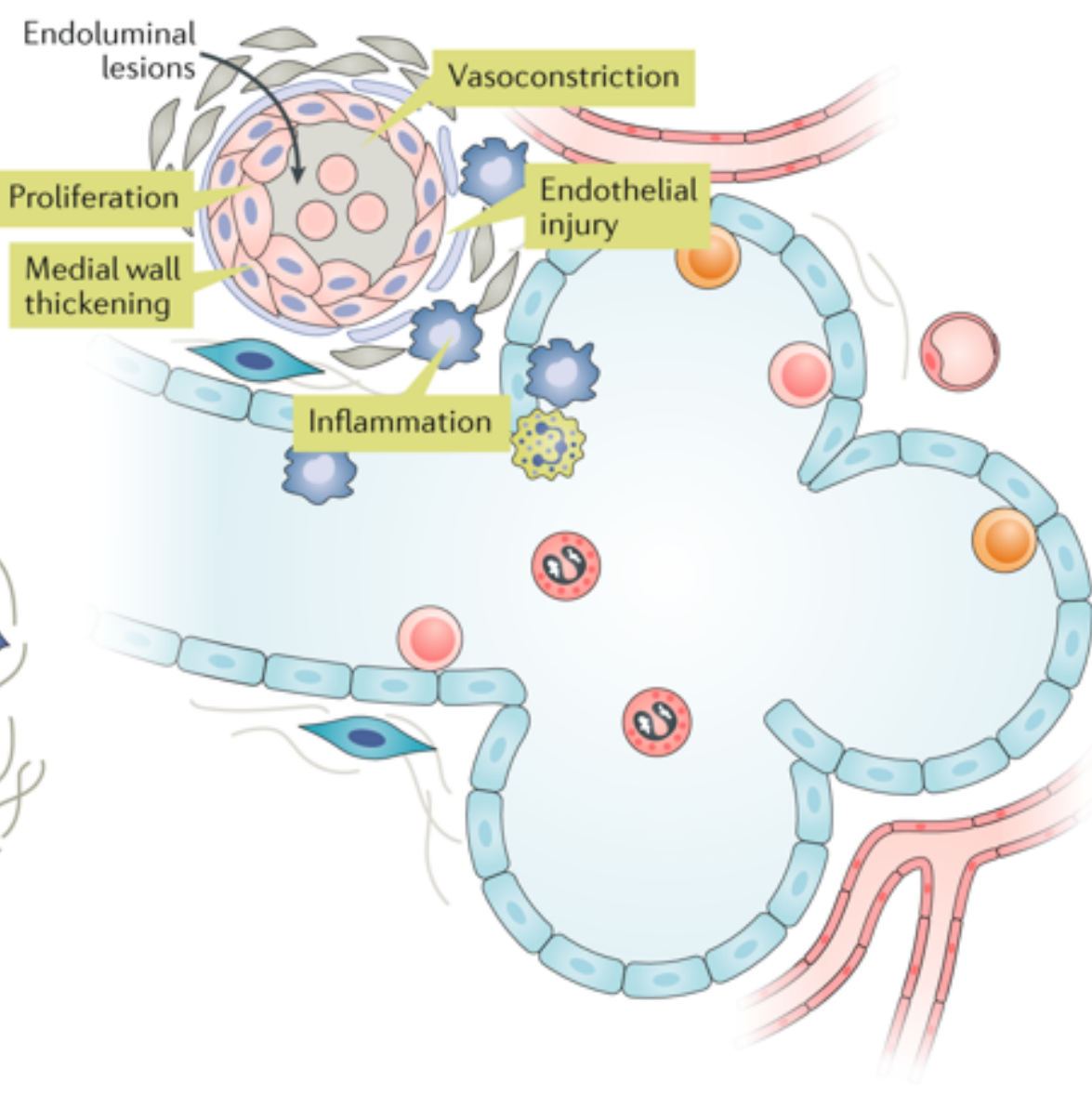


- Increased breathlessness

- Reduced exercise tolerance

- Presyncope

- Features of right heart failure

- Chest pain

\section{Initial screening}

- Lung function test (including DLco)

- Transthoracic echocardiogram

- NT-proBNP

- DETECT algorithm if DLco $<60 \%$ and $>3$ years disease duration

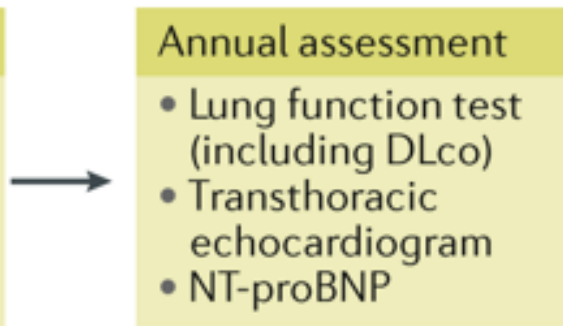

- NT-proBNP

\section{Triggered assessment}

- Lung function test (including DLco)

- Transthoracic echocardiogram

- NT-proBNP

$$
\downarrow
$$

\section{DETECT composite measure}

- Score $>35$ even without symptoms of pulmonary hypertension

$$
\downarrow
$$

\section{Transthoracic echocardiogram}

- Tricuspid regurgitation velocity $>2.8 \mathrm{~m} / \mathrm{s}$

- Tricuspid regurgitation velocity $2.5-2.8 \mathrm{~m} / \mathrm{s}$ with relevant symptoms of pulmonary hypertension

- Enlargement of right atrium (major dimension $>53 \mathrm{~mm}$ ) or right ventricle (mid-cavity dimension $>35 \mathrm{~mm}$ ), irrespective of tricuspid regurgitation velocity

\section{Pulmonary function test}

- FVC:DLco ratio $>1.6$ and/or DLco $<60 \%$ with symptoms of pulmonary hypertension

- FVC:DLco ratio >1.6 and/or DLco $<60 \%$ and NT-proBNP more than twice the upper limit of normal even without symptoms of pulmonary hypertension

\section{Recommend cardiac catheterisation}

\footnotetext{
- Pulmonary hypertension defined by $\mathrm{mPAP} \geq 25 \mathrm{~mm} \mathrm{Hg}$ and PVR $\geq 3 \mathrm{WU}$
}

- PAH requires PAWP $\leq 15 \mathrm{~mm} \mathrm{Hg}$ and no major lung fibrosis 
c UIP
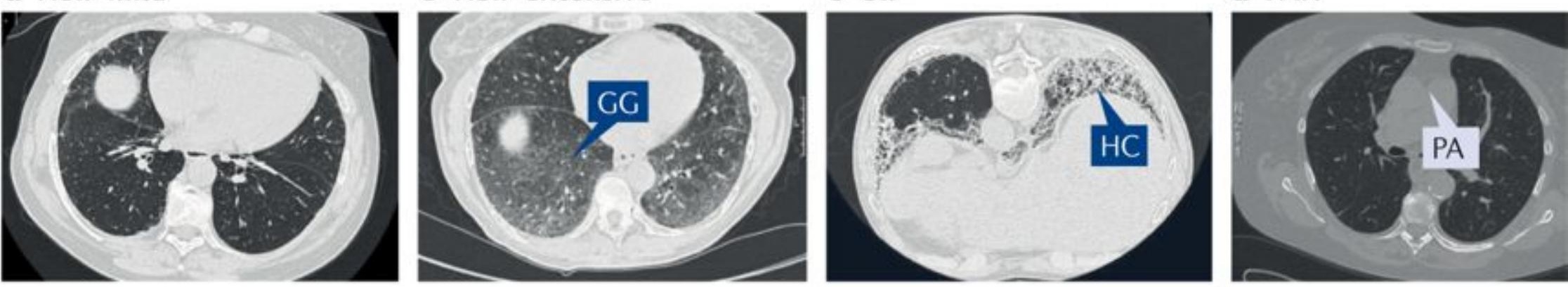

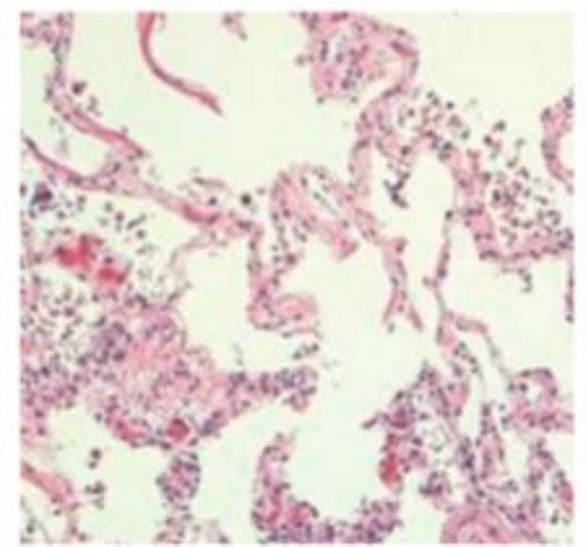

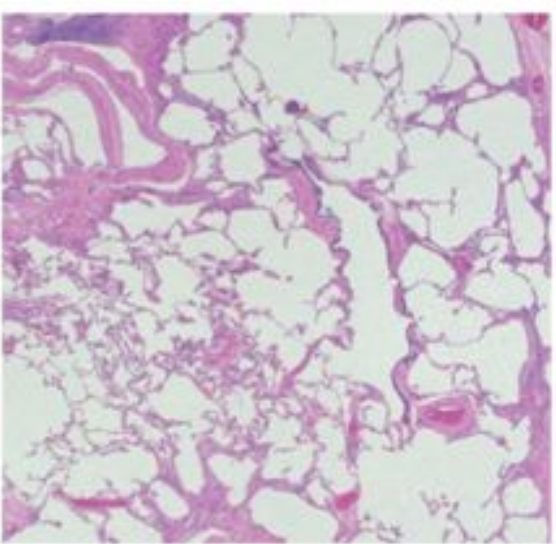

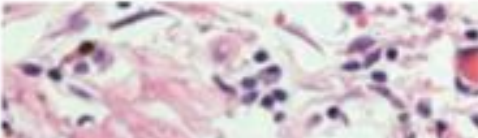
ing

स 165

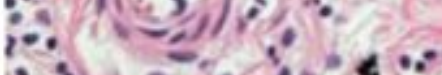
$\because 4,3,2,4,401$

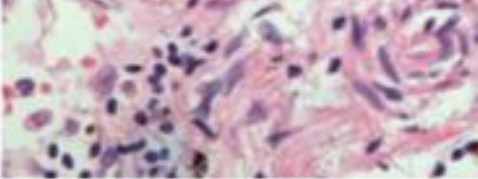

